\title{
STRATIGRAPHY, CHRONOLOGY AND PALAEONTOLOGY OF THE TERTIARY ROCKS OF THE CHERINGOMA PLATEAU, MOZAMBIQUE
}

\author{
MARION BAMFORD ${ }^{1}$, MARTIN PICKFORD2,* \\ ${ }^{1}$ Evolutionary Studies Institute, University of the Witwatersrand, Private Bag 3, Johannesburg, 2050 South Africa; \\ e-mail: Marion.Bamford@wits.ac.za. \\ 2 Département Origines \& Evolution, Muséum National d'Histoire Naturelle, CR2P-UMR 7207 MNHN-CNRS-Sorbonne Université, CP 38, \\ 43 rue Buffon, Paris, 75005 France; e-mail: martin.pickford@mnhn.fr. \\ * corresponding author
}

Bamford, M., Pickford, M. (2021): Stratigraphy, chronology and palaeontology of the Tertiary rocks of the Cheringoma Plateau, Mozambique. - Fossil Imprint, 77(1): 187-213, Praha. ISSN 2533-4050 (print), ISSN 2533-4069 (on-line).

\begin{abstract}
The discovery of fossil plants, marine molluscs and mammals in the Mazamba Formation, Cheringoma Plateau, Mozambique, opens a new chapter in the study of this part of the African Rift System. The evidence suggests that the Mazamba Formation is older than previously reported, probably late Eocene rather than Miocene. The fossil wood and stems indicate a frost-free tropical humid environment and a high water table soon after deposition, and the marine molluscs and mammals indicate proximity to the sea. There is also evidence for the occurrence of pans in the area during the late Eocene which also suggest a near-surface water table.

This paper discusses the history of interpretation of the geology of the Cheringoma Plateau and describes and interprets the fossil plants, molluscs and mammals collected in 2012 and 2013. It is concluded that the Mazamba Formation, which overlies the fully marine Lutetian-Bartonian Cheringoma Limestone, is a coastal facies (fluvio-deltaic, lagoonal and onshore deposits) that accumulated on top of the marine limestones as sea level dropped late in the Bartonian. Mammalian bones from the White Patch sites represent a heavily built species about the dimensions of a pygmy hippopotamus, probably belonging to the order Embrithopoda. If so, then the Mazamba Formation is likely to correlate to the latest Bartonian or early Priabonian rather than to the Miocene as previously assumed.
\end{abstract}

Key words: stratigraphy, biochronology, depositional environments, Cheringoma Plateau, East African Rift System, palaeontology

Received: June 29, 2021 | Accepted: September 10, 2021 | Issued: December 9, 2021

\section{Introduction}

The stratigraphic relationships of the sedimentary and volcanic rocks of the Cheringoma Plateau, Gorongosa Park, Mozambique, appear, from a first glance of the literature, to be reasonably well established (Real 1966, Tinley 1977, Laumanns 2001, GTK Consortium 2006, Steinbruch 2010, Grantham et al. 2011, Scoon 2016). Yet a close examination reveals deep inconsistencies in the interpretations of the ages of these deposits, the order in which they accumulated and the large ranges of age errors that some of the rock units have.

The geological maps and sections that accompany these publications show divergent schemas indicating that there are problems of correlation and of interpretation of the field relationships of the rock units to each other. Errors that have been introduced (GTK Consortium 2006) such as misreporting the previously established succession of strata
(Real 1966, Tinley 1977) have been repeated (Grantham et al. 2011, Scoon 2016) while some redrawn maps have placed certain rock outcrops in the wrong position (Tinley 1977) or have omitted them entirely (GTK Consortium 2006). Furthermore, the word "Mazamba" has been employed for diverse concepts - a mappable formation in its type area, a chronostratigraphic unit in well logs (usually said to be Miocene or Mio-Pliocene), and a sedimentary facies in well $\operatorname{logs}$ - and the name has been applied to strata elsewhere in Mozambique that are far removed from the Cheringoma Plateau, mainly on the grounds that the deposits yield Miocene fossils. However, the Miocene age of the deposits attributed to the Mazamba Formation in its type area, the Cheringoma Plateau, has never been convincingly demonstrated.

In many recent publications, there has been a curious absence of references to studies of Mozambiquan geology carried out before the Second World War. 
The aim of this paper is threefold:

(1) to provide a historical perspective of the geological surveys carried out in the Cheringoma Plateau, to point out the various uncertainties that exist and to propose a way forwards;

(2) to discuss the implications of the discovery of fossil plants, invertebrates and vertebrates in the Mazamba Formation (Pickford 2012, 2013, Habermann et al. 2019) which represents a crucial breakthrough that will undoubtedly throw light on the timing of geological events in the region;

(3) to describe the silicified plant remains and animal fossils collected by the second author during the 2012 and 2013 field surveys.

\section{Historical perspective}

At the time of the pioneering geological studies of the Cheringoma Plateau, the Geological Time Scale used by many geologists was rather different from what it is today. For geologists such as Kaiser (1926) working in South-West Africa (now Namibia), Dartevelle (1935) working in Cabinda, Angola, and Thiele (Thiele and Wilson 1915, Teale 1924) working in Mozambique, the Cretaceous was followed by the Eocene, which was followed by the Miocene (i.e., the Palaeocene and Oligocene were not recognised by these authors as distinct chronostratigraphic units). Thus, the time slots into which strata were arranged by them spanned rather different periods from what they would be had they employed the currently accepted time scale (Gradstein et al. 2020). The Oligocene, for example, even though it had been coined by Beyrich (1854), was not utilised by many authors until well into the $20^{\text {th }}$ Century (Pickford 2015) being formally accepted in the United States of America as late as 1939 (Berggren 1998). For this reason, when reading articles published prior to the Second World War, one needs to keep in mind the differences in time scales employed by the geologists and palaeontologists of that era, from those employed in more recent times.

The case of Cabinda in Angola provides a clear example of the hazards arising from employing the old time scale. The mammal-bearing deposits at Malembe were correlated by Dartevelle (1935) to the Miocene on the grounds that they overlie the Lutetian Landana Formation and he attributed the fossils from the unit to characteristic Miocene taxa, thereby "confirming" the proposed correlation. Hooijer (1963) accepted the Miocene age and also attributed the fossils to typically Miocene genera such as the chalicothere Macrotherium, the suid Palaeochoerus, an amphicyonid carnivore, a zygodont proboscidean and an anthracothere. It wasn't until Pickford $(1986,1987)$ studied the fossils that the fauna was realised to belong to early Oligocene taxa, the so-called chalicothere fossil being from an arsinoithere, the "Palaeochoerus" specimen being a bunodont hyracoid (Geniohyus), the "amphicyonid upper incisor" being a primate lower canine, the zygodont molar being from a primitive proboscidean (Phiomia), and the erstwhile "anthracothere" tooth being another species of hyracoid. Thus, instead of being about 18-20 million years old as thought by Hooijer (1963) the deposits at Malembe are closer in age to 33-34 million years.

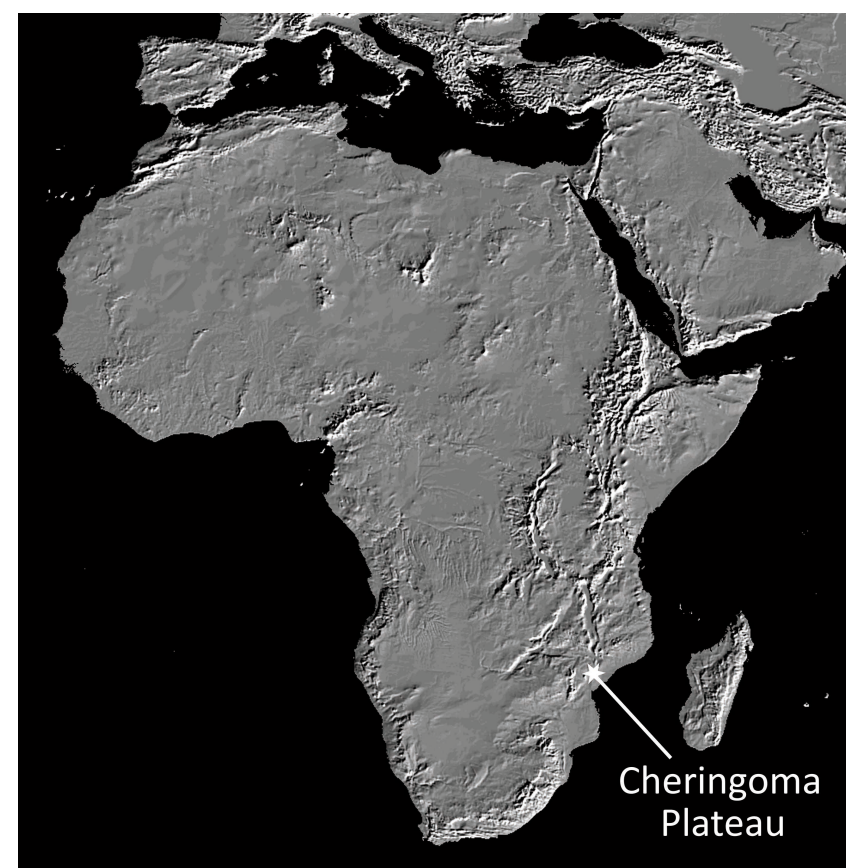

Text-fig. 1. Relief map of Africa to show the location of the Cheringoma Plateau at the southern extremity of the African Rift System.

This outdated "abbreviated" time scale continued to be used (unwittingly) by some authors as recently as Tinley (1977) who did not mention the Palaeocene or Oligocene time slots in their treatments of the stratigraphy of Gorongosa Park and environs in Mozambique (Text-fig. 1).

One of the first reports of the presence of fossiliferous strata in the Cheringoma (Sheringoma) region was by Thiele and Wilson (1915: 33 and geological map on p. 29; Newton 1915). These authors briefly mentioned the presence of "marine sediments ranging from Upper Cretaceous to Middle Tertiary, its top consisting for the most part of a Miocene foraminiferal limestone". The authors inferred a postMiocene age of the tectonic movement of the Cheringoma block in which these strata are exposed.

In his 1924 paper Teale corrected the previous report concerning the age of the Cheringoma strata: "Three genera of echinoids are recorded by Mr. Bullen Newton. These, together with the nummulites, establish the Eocene age of the beds, for these limestones were originally regarded as Miocene in age, being thus indicated in a geological map accompanying the paper by Mr. Wilson and myself in the Geographical Journal, January, 1915". In the same 1915 map, the outcrops labelled as Eocene are nowadays considered to correlate to the Cretaceous and Palaeocene, comprising local occurrences of the Sena and Grudja formations.

Newton (1924) pointed out that the Miocene correlation of the foraminiferal limestone at Cheringoma initially proposed by Thiele and Wilson (1915) was based on the identification of Amphistegina in it, but that closer examination of the fossils revealed that they comprised a small form of Nummulites allied to $N$. variolaria, which implied an Eocene instead of a Miocene correlation.

Following these pioneer surveys, further studies were carried out, notably by oil company geologists, but few of the details have been published, the data being in the nature 
Table 1. Stratigraphic succession proposed by Real (1966).

\begin{tabular}{|l|l|l|}
\hline \multicolumn{1}{|c|}{ Map symbol } & \multicolumn{1}{c|}{ Lithology } & \multicolumn{1}{c|}{ Correlations } \\
\hline $\mathbf{a}$ & Areias brancas e vermelhas & Antropozoico \\
\hline $\mathbf{M P m}$ & Mio-Pliocéno marinho & Cenozoico \\
\hline $\mathbf{E m}$ & Eocénico marinho & Cenozoico \\
\hline $\mathbf{C m}$ & Cretàcico marinho (Senoniano) & Cretàcico superior \\
\hline $\mathbf{C c}$ & Cretàcico continental, Grés de Sena (Turoniano); englobe também formaçőes mais antigas, juràssicas & Cretàcico superior \\
\hline
\end{tabular}

of unpublished reports (Flores 1964) although there are some synthesised publications (Real 1966, Flores 1973, Tinley 1977) dealing with regional geological patterns. As far as the authors have determined, apart from the rudimentary sketches of sections included in the paper by Newton (1924: 144-145) which show only estimated thicknesses,
Inhaminga". The basal purple grits were correlated by him to the Miocene and he reported the presence of marine fossils in the unit, including foraminiferans (Nummulites, Quinqueloculina, Robulus), molluscs (Ostrea, Protocardia, Pecten, Turritella) and a crab (Cancris) all of which indicated to him that the deposits accumulated in littoral

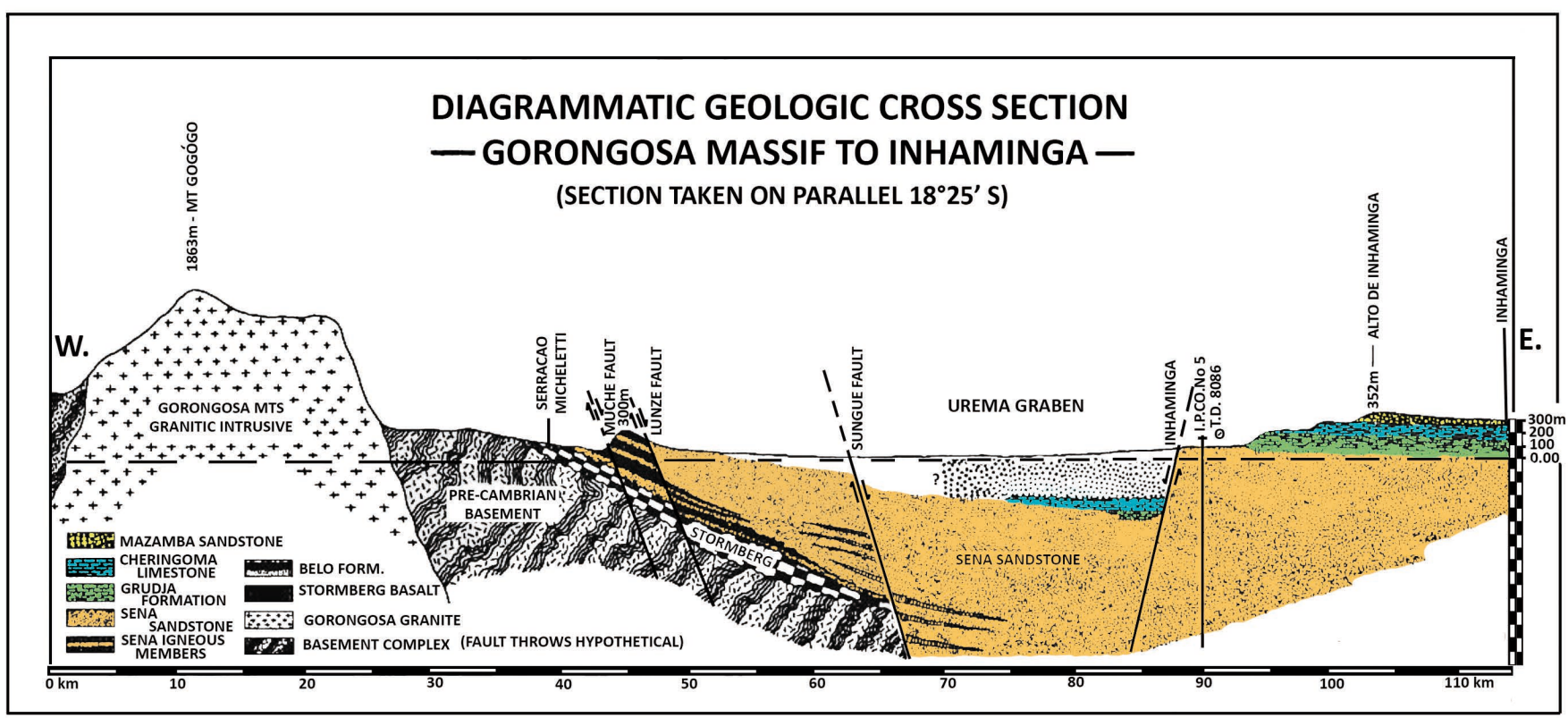

Text-fig. 2. E-W cross section of the Urema Graben from Gorongosa to Inhaminga adapted from Flores (1973: fig. 5). Note that in this schema the Mazamba Sandstone directly overlies the Cheringoma Limestone. I.P.CO No. 5 is a bore hole. Vertical exaggeration $\times 10$.

but without lithological details, no detailed stratigraphic successions of the Cheringoma region have been published. Large-scale cross sections have been included in several reports by Flores (1973), Tinley (1977) and Pfaffhuber et al. (2009) but even these show little detail and in parts the geological relationships appear to be contentious (Textfig. 4).

One of the earliest published stratigraphic successions of the eastern shoulders of the Urema Rift, comprising the Cheringoma Plateau was by Real (1966) (Tab. 1). He mentioned that a K-Ar age determination of $46 \mathrm{Ma}$ was obtained from glauconite from the upper part of the Grudja Formation, the lower part of which was correlated to the Cretaceous. No details of the analyses which yielded the age of $46 \mathrm{Ma}$ were published.

In the text, Real (1966) described the "Formação de Mozambo" which comprised two units, the "Grés de cor purpura" at the base, overlain by the "Camadas de marine environments possibly with deltaic intercalations. The overlying Inhaminga beds were correlated by Real (1966) to the Mio-Pliocene, but he wrote that the deposits were unfossiliferous.

Flores (1973: figs 3, 5) published stratigraphic correlations of the areas northwest of Beira and the Lower Zambezi, based mainly on well data (Text-fig. 2). The succession "NW of Beira" comprises Sena Formation at the base $(8,000$ feet thick - ca. 2,700 m) followed by the Grudja Formation (200 feet thick - ca. $70 \mathrm{~m}$ ) followed by a hiatus, followed by the Cheringoma Formation (Carbonate Member) (200 feet thick - ca. $70 \mathrm{~m}$ ) followed by a hiatus, followed by the Mazamba Formation (460 feet thick - ca. $150 \mathrm{~m}$ ). In the Lower Zambezi, the succession is similar with the exceptions that there is no hiatus between the Grudja and Cheringoma units, and there is the Inharrime Formation above the Cheringoma Formation (carbonate member), with a hiatus between it and the Mazamba Formation. The 
Table 2. Stratigraphic succession in the Gorongosa-Cheringoma region proposed by Tinley (1977).

\begin{tabular}{|l|l|l|l|}
\hline \multicolumn{1}{|c|}{ Map symbol } & \multicolumn{1}{c|}{ Lithology } & \multicolumn{1}{c|}{ Formation } & \multicolumn{1}{c|}{ Correlation } \\
\hline $\mathbf{t}$ & Talus & & Recent \\
\hline $\mathbf{Q A}_{\mathbf{1}}$ & Alluvium & & Recent \\
\hline $\mathbf{Q c}$ & Colluvial Fan Detritus & & Recent \\
\hline $\mathbf{Q P}_{\mathbf{1}}$ & Sandy Eluvium & & Pleistocene \\
\hline $\mathbf{Q P}_{\mathbf{2}}$ & Sandy-Clay Eluvium & & Pleistocene \\
\hline Bal & Nepheline Basalt & & Mio-Pliocene \\
\hline $\mathbf{T T s}_{\mathbf{2}}$ & Inhaminga sandstone quartzitic and conglomeratic & Mazamba Formation & Mio-Pliocene \\
\hline $\mathbf{c h}$ & Chert & Mazamba Formation & Mio-Pliocene \\
\hline $\mathbf{T T} \mathbf{1}_{\mathbf{1}}$ & Red sandstone quartzitic limestone & Mazamba Formation & Mio-Pliocene \\
\hline $\mathbf{T T i}$ & Nummulitic Limestone glauconitic sandstone basally & Cheringoma Formation & Eocene \\
\hline Ksm & Calcareous and glauconitic sandstone & Grudja Formation & Cretaceous \\
\hline Ksc & Arkosic sandstone (calcic-argillaceous cement) & Sena Formation & Cretaceous \\
\hline
\end{tabular}

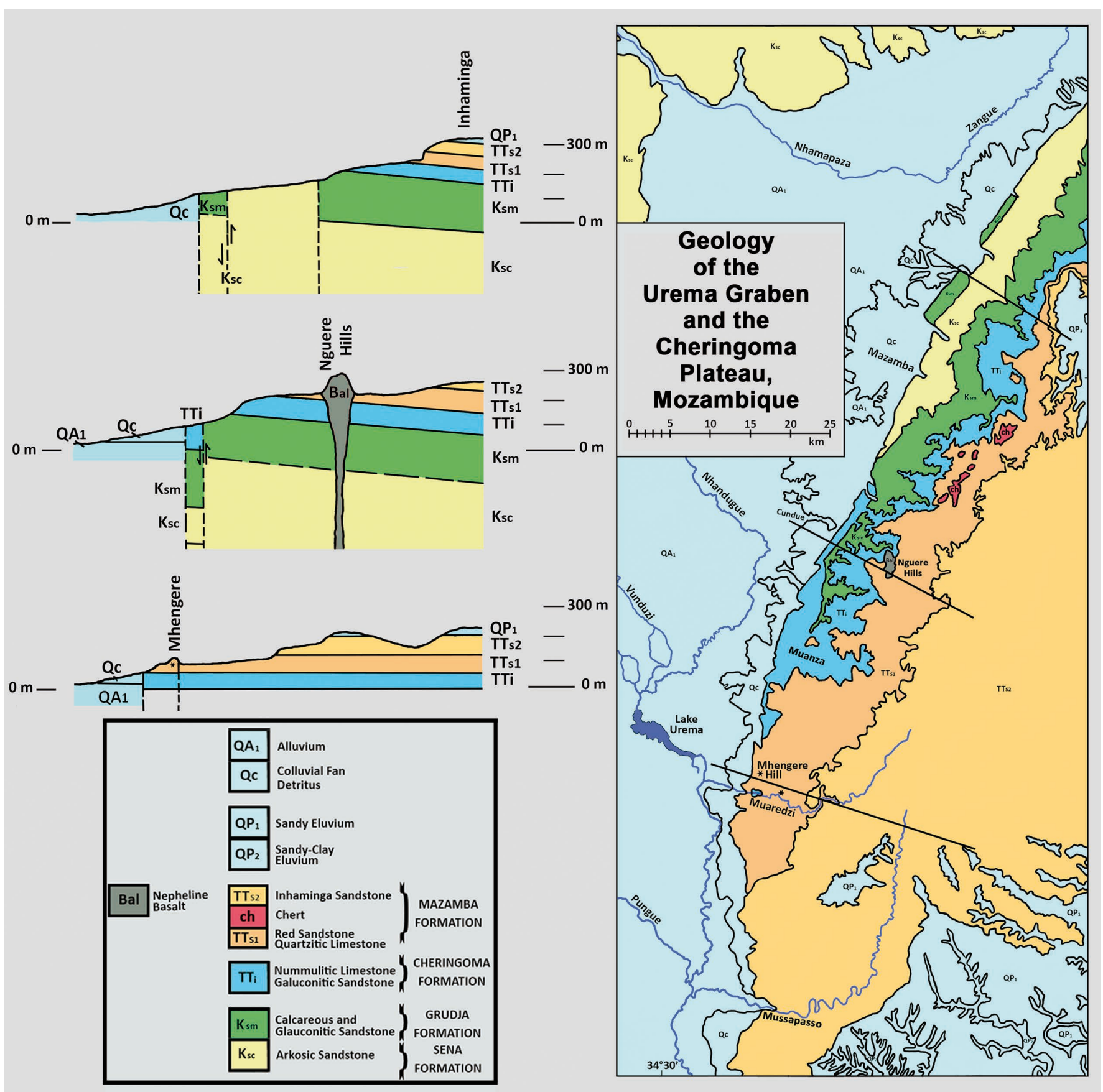

Text-fig. 3. Geology of the Cheringoma Plateau, Mozambique. Sections and geological map adapted from Tinley (1977). The star symbols close to Mhengere Hill represent fossil wood and stem sites. Note that the fault relationships proposed in the northernmost Inhaminga section require re-examination. The Nguere Hills were called Gadjiua by Tinley (1977). 


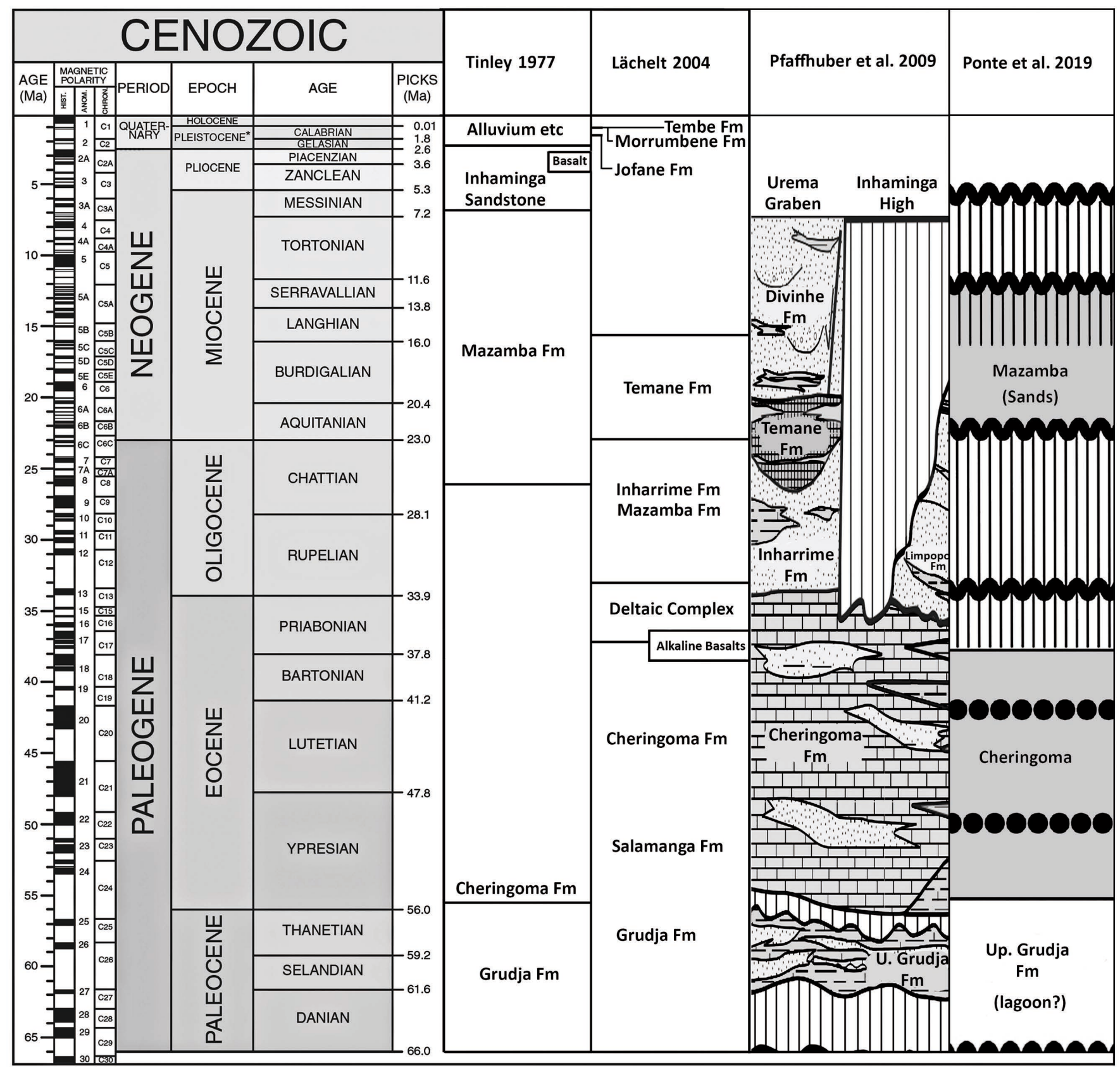

Text-fig. 4. Correlations of the strata in the Urema Graben, the Cheringoma Plateau and other parts of Mozambique proposed by various authors. The positions of fossiliferous units such as the Grudja and Cheringoma formations have been reasonably stable, whereas correlations of other rock units, especially the Mazamba Formation and the volcanics, have varied a great deal. The time scale is from Gradstein et al. (2020).

geological maps and regional sections are at too large a scale to yield additional information, but they provide an overview of the outcrop patterns and the structural relationships of the Cheringoma Plateau to the Urema Graben.

In his comprehensive study of the Gorongosa Park, Tinley (1977) published a monochrome geological map in which he subdivided the Cheringoma rock sequence into the following units (Text-fig. 3, Tab. 2).

Note in particular that, following Real (1966), Tinley (1977) called the upper subunit of the Mazamba Formation the Inhaminga sandstone $\left(\mathrm{TTs}_{2}\right)$ and positioned it younger than both the chert facies (ch) and the basal subunit $\left(\mathrm{TTs}_{1}\right)$ of the formation. According to Tinley (1977) the chert is comprised of silicified lime and sandstone of the Tertiary sediments, and is thus not a distinct stratigraphic unit, but is an alteration product of pre-existing strata.

Lächelt (2004: folder 4) correlated the Mazamba Fms (sic) to the lower Oligocene, and separated them from the Cheringoma and Salamanga formations by an un-named Deltaic Complex of late Eocene age (Text-fig. 4). He also estimated the age of the alkaline basalts as late Eocene. He correlated the Inharrime Formation to the Oligocene, with the Temane Fm correlating to the early Miocene.

Confusingly, the legend of the GTK Consortium (2006) geological map sheet 1834 (Tab. 3) positions the Inhaminga Formation (TeI) beneath the Cheringoma Formation (TeC) with the Mazamba Formation (TeZ) as the youngest of the Tertiary rocks in the region. The map in contrast shows the 
Table 3. Stratigraphic succession in the Cheringoma Plateau proposed by Ferrara and Manninen (2006), GTK Consortium (2006).

\begin{tabular}{|l|l|l|l|}
\hline \multicolumn{1}{|c|}{ Map symbol } & \multicolumn{1}{c|}{ Formation } & \multicolumn{1}{c|}{ Lithology } & \multicolumn{1}{c|}{ Correlations } \\
\hline Qa & & Aluviăo, areia, silte, cascalho & Quaternary \\
\hline Qps & & Escorręncia argilo-arenoso fluvial & Quaternary \\
\hline Qc & & Coluviăo & Quaternary \\
\hline TeZ & Mazamba & Grés arcosico, parcialmente conglomeratico & Tertiary \\
\hline TeC & Cheringoma & Calcario, grés glauconitico & Tertiary \\
\hline TeI & Inhaminga & Grés & Tertiary \\
\hline CrG & Grudja & Marga, silte, calcario, gesso & Cretaceous \\
\hline CrSb & Sena & Membro conglomeratico basal, grés conglomeratico & Cretaceous \\
\hline
\end{tabular}

Inhaminga Formation overlying the Cheringoma Formation, and underlying the Mazamba Formation. Thus, in the map, the position of the Inhaminga subdivision of the Mazamba Formation as presented prior to 2000, has been inverted such that it is now the oldest of the strata overlying the Cheringoma Formation rather than being the younger subunit of the Mazamba Formation as originally defined.

Pfaffhuber et al. (2009) correlated the sediments immediately overlying the Eocene limestone in the vicinity of Inhaminga to the Oligocene (Text-figs 4, 5). In their interpretation of the geology of the Urema Graben and Inhaminga High, the only occurrence of Miocene strata in the region is within the Urema Graben itself.

Ponte et al. (2019) correlated the Cheringoma Formation to the Ypresian-Bartonian (Text-fig. 4), whereas Pfaffhuber et al. (2009) considered that the Cheringoma Formation spans the entire Eocene from the base of the Ypresian to the end of the Priabonian (Text-fig. 4). Another difference in interpretations is that some authors considered that no deposits accumulated in Mozambique during the Oligocene (Tinley 1977, Ponte et al. 2019) whereas some (Flores 1973, Pfaffhuber et al. 2009) saw no hiatus in deposition, just a lateral shift (oceanward) in facies during this period.

Supposedly intruding the Cheringoma sedimentary succession is the volcanic complex of the Nguere Hills (called Inkweyri by Thiele and Wilson 1915, Nkweri by Teale 1924, Inkweri by Mennell 1929, N'Guere by Real 1966, Gadjiua by Tinley 1977, and Nguére by Ferrara et al.
2006) which crops out close to the crest of the Cheringoma Plateau, $40 \mathrm{~km}$ from Inhaminga at a bearing of $220^{\circ}$ (at $\left.18^{\circ} 42^{\prime} 24^{\prime \prime} \mathrm{S}: 34^{\circ} 46^{\prime} 02^{\prime \prime} \mathrm{E}\right)$. The estimated age of the basalts in these hills has varied in the literature from late Eocene (Lächelt 2004), post-Eocene (Teale 1924), Oligocene (Steinbruch 2010), Miocene (Lächelt 2004) and Pliocene (Tinley 1977, Steinbruch 2010) and their composition from ultrabasic (Mennell 1929) to nepheline basalt (Real 1966) to olivine basalt (Real 1966) to rhyolite (Steinbruch 2010). These volcanic outcrops are missing from the GTK Consortium (2006) map.

As a result of these conflicting interpretations and omissions, the timing of geological events in the Cheringoma Plateau is far from being well-established, as are correlations to other formations in the country. For example, from below to above, the Temane, Inharrime and Jofane formations are often correlated to the Miocene (Flores 1973, Said et al. 2015) as are the Mazamba and Inhaminga formations (Tinley 1977) suggesting that they are penecontemporaneous. However, some authors such as Pfaffhuber et al. (2009) correlate these formations to the Oligocene and even have them in a different stratigraphic order (Inharrime Formation beneath the Temane Formation) and the younger Divinhe Formation correlated to the Miocene, spanning the same period in which other authors place the Mazamba Formation. Furthermore, Pfaffhuber et al. (2009) considered that the Inharrime Formation is a lateral equivalent of the lower part of the Limpopo Formation.

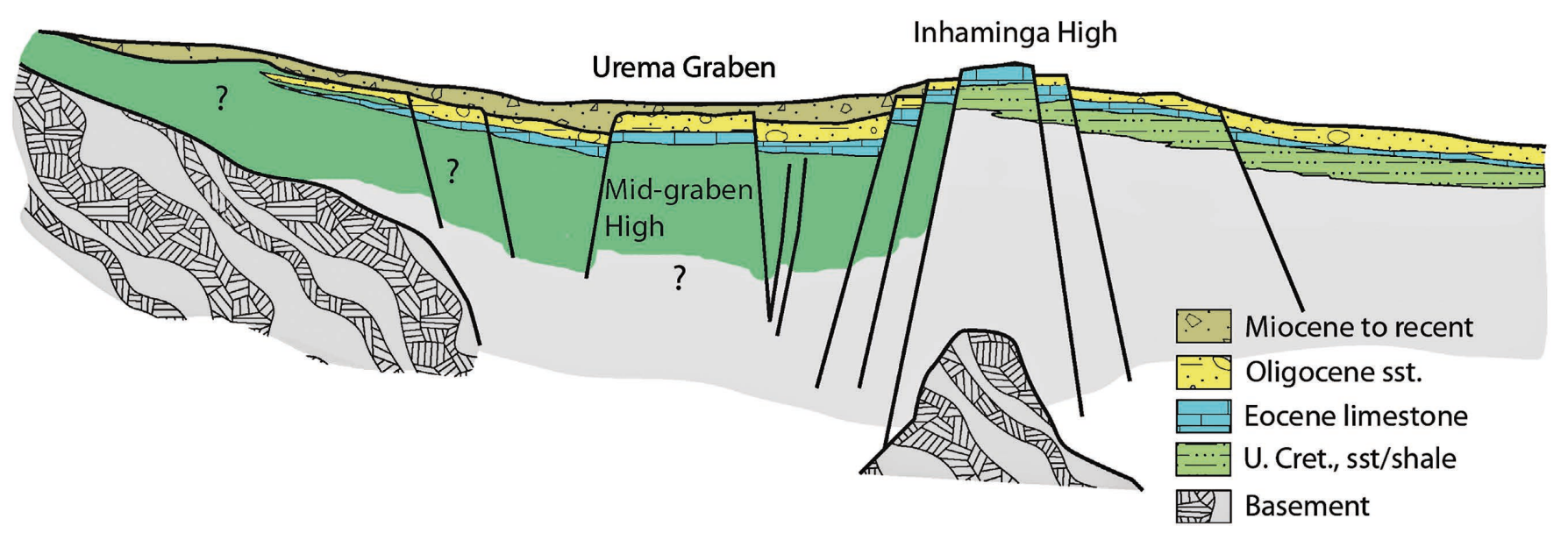

Text-fig. 5. East-west cross section of the Urema Graben and Cheringoma Plateau adapted from Pfaffhuber et al. (2009). The Urema Graben is ca. $\mathbf{4 5 - 5 0 ~} \mathbf{~ k m}$ broad. Note that in this scheme, the Eocene Limestone (i.e., the Cheringoma Fm) is overlain by Oligocene sandstone in the position mapped as Mazamba Formation by Real (1966) and by Tinley (1977). 


\section{The Cheringoma Limestone}

After first being correlated to the Miocene (Thiele and Wilson 1915), the Cheringoma carbonates were attributed to the Eocene after re-examination of the microfauna that they yielded (Teale 1924, Newton 1924). This correlation has been generally accepted by all subsequent workers, although its position within the Eocene has been somewhat fluid, but usually centred on the Lutetian - Bartonian.

Abrard (1928) was among the early scientists to estimate the age of the Cheringoma Limestone. He studied samples collected and donated to the Paris Museum by Mr Surcouf. In his first sample (A in Tab. 4) he recorded Nummulites atacicus $(=N$. biarritzensis), Orthophragmina (O. cf. pratti, and ?O. sella), and echinoids. On this basis he estimated that the limestone containing Nummulites atacicus and $O$. cf. pratti correlated to the Lutetian. He considered that the pinkish limestone (B in Tab. 4) with $O$. cf. pratti and ?O. sella, would correlate to the boundary between the Lutetian and the Bartonian. Finally, in citing Newton's work (in the appendix of Teale 1924) (C in Tab. 4) he suggested that samples from Cheringoma containing Nummulites $\mathrm{cf}$. variolarius and $O$. cf. pratti likely represent a third level which correlates to the base of the Bartonian.

If the identifications and interpretations of Abrard (1928) are correct, then the samples containing Nummulites atacicus would correspond to SBZ 8 (Shallow Benthic Zone 8) of Serra-Kiel et al. (1998) (early Ypresian ca. $54 \mathrm{Ma}$ ), the samples with $O$. cf. pratti and $O$. sella, would correlate to SBZ 17 - SBZ 18 (early to late Bartonian, ca. 43-37 Ma), and the third set containing Nummulites cf. variolarius and $O$. cf. pratti, to SBZ 17 (or possibly SBZ 16, late Lutetian to Bartonian). However, the identification of $N$. atacicus needs to be verified in view of Abrard (1928) equating it with $N$. biarritzensis which is a younger species. The association of the latter species with Orthophragmina cf. pratti would suggest a younger correlation than SBZ 8, or if the identification of $N$. atacicus is correct, then it might be based on reworked specimens. There are several subspecies of Discocyclina pratti which have different stratigraphic distributions (Tab. 4) but neither Newton (1924) nor Abrard (1928) employed subspecies. Without further precision, all that can be inferred from the presence of $D$. pratti in the Cheringoma Formation is that the limestones could correlate to SBZ 13 to SBZ 19.

According to Real (1966) the Cheringoma Formation, which overlies the Grudja Formation, has yielded
Nummulites sp. and Nummulites atacicus, discocyclines, echinoids, bryozoaires, gastropods, and calcareous algae such as Lithothamnion sp. On this basis he estimated a correlation to the middle and late Eocene. The limestones also yielded a calcareous worm, Tubulostium cyclaminoides.

The Mazamba Formation, which overlies the Cheringoma Formation, has yielded molluscs (Turritella sp., Ostrea sp., Protocardia sp., Pecten sp.), foraminiferans (Nummulites sp., Quinqueloculina, Robulus) and crustaceans (Cancris) (Real 1966).

Tinley (1977) correlated the Mazamba Formation to the Mio-Pliocene "(Age: between 7 and 26 m.y.)". He subdivided the formation into three units, comprising red sandstone, quartzitic limestone at the base $\left(\mathrm{TTs}_{1}\right)$, a chert unit (ch) in the middle and the Inhaminga quartzitic sandstone and conglomerate $\left(\mathrm{TTs}_{2}\right)$ at the top which he considered to be "probably Pliocene". The chert silicification affected Eocene and subsequent deposits, but it is not a distinct depositional episode - just an alteration of pre-existing sediments. He proposed that the upper unit of the Mazamba Formation was intruded by nepheline basalt (Bal). Concerning the Tertiary volcanics he wrote "Piercing the above sedimentary strata in the central western part of the plateau is a volcanic neck of nepheline basalt. This Pliocene Intrusion is today a low rounded inselberg rising to $345 \mathrm{~m}$, its summit at about the same level as the highest plateau remnant near Inhaminga which attains $379 \mathrm{~m}$ above sea level".

Laumanns (2001) described the caves and other karst phenomena of the Cheringoma area. In his geological map he recognised only the Inhaminga Sandstone (TTs) overlying the Cheringoma Limestone (TTi) but in the text he described the Mazamba Formation $\left(\mathrm{TTs}_{1}-\mathrm{TTs}_{2}\right)$ as "lying in normal discordance (sic) above the corroded surface of the Cheringoma limestone" with $\mathrm{TTs}_{2}$ consisting "of the socalled Inhaminga sandstone". These units were considered to be "predominantly Miocene and also Pliocene age". Laumanns (2001) proposed that there were two phases of karstification of the Cheringoma Limestones "one of post Eocene age and a younger one of Pleistocene age".

Steinbruch (2010) provided a summary of the geology of Gorongosa Park. Concerning the Cheringoma Plateau, called by her the Inhaminga Block, she wrote "The arkose sandstones and limestones were intensively karstified during Eocene and re-filled during Miocene (Laumanns, 1998 - 2001 was meant). Head erosion along the eastern rift flank has partly removed the sediment fill from the fossil

Table 4. Distribution of foraminiferans identified by Abrard (1928) (A, B) and Newton (1924) (C) from Cheringoma, Mozambique. The SBZ scale is from Serra-Kiel et al. (1998). $\mathrm{X}$ - stratigraphic distribution of subspecies of Discocyclina pratti.

\begin{tabular}{|c|c|c|c|c|c|c|c|c|c|c|c|c|}
\hline Taxon / SBZ & 8 & 9 & 10 & 11 & 12 & 13 & 14 & 15 & 16 & 17 & 18 & 19 \\
\hline Nummulites atacicus & A & & & & & & & & & & & \\
\hline Nummulites $\mathrm{cf}$. variolarius & & & & & & & & $\mathrm{C}$ & $\mathrm{C}$ & $\mathrm{C}$ & & \\
\hline Nummulites biarritzensis & & & & & & & & & & A & & \\
\hline Discocyclina pratti & & & & & & $\mathrm{ABC}$ & $\mathrm{ABC}$ & $\mathrm{ABC}$ & $\mathrm{ABC}$ & $\mathrm{ABC}$ & $\mathrm{ABC}$ & $\mathrm{ABC}$ \\
\hline Discocyclina dispansa sella & & & & & & & & $\mathrm{AB}$ & $\mathrm{AB}$ & $\mathrm{AB}$ & $\mathrm{AB}$ & \\
\hline D. pratti monfortensis & & & & & & $\mathrm{X}$ & $\mathrm{X}$ & $\mathrm{X}$ & $\mathrm{X}$ & & & \\
\hline D. pratti pratti & & & & & & & & & & $\mathrm{X}$ & $\mathrm{X}$ & $\mathrm{X}$ \\
\hline D. pratti minor & & & & & & & & & & & & $\mathrm{X}$ \\
\hline
\end{tabular}




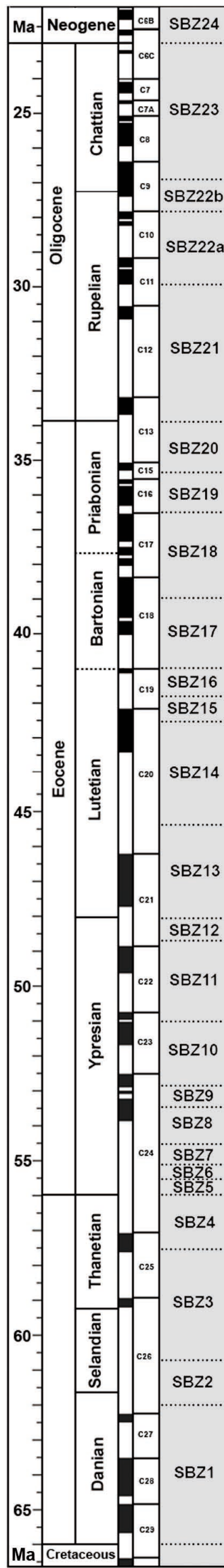

\section{Cheringoma Formation Shallow Benthic Foraminifera}
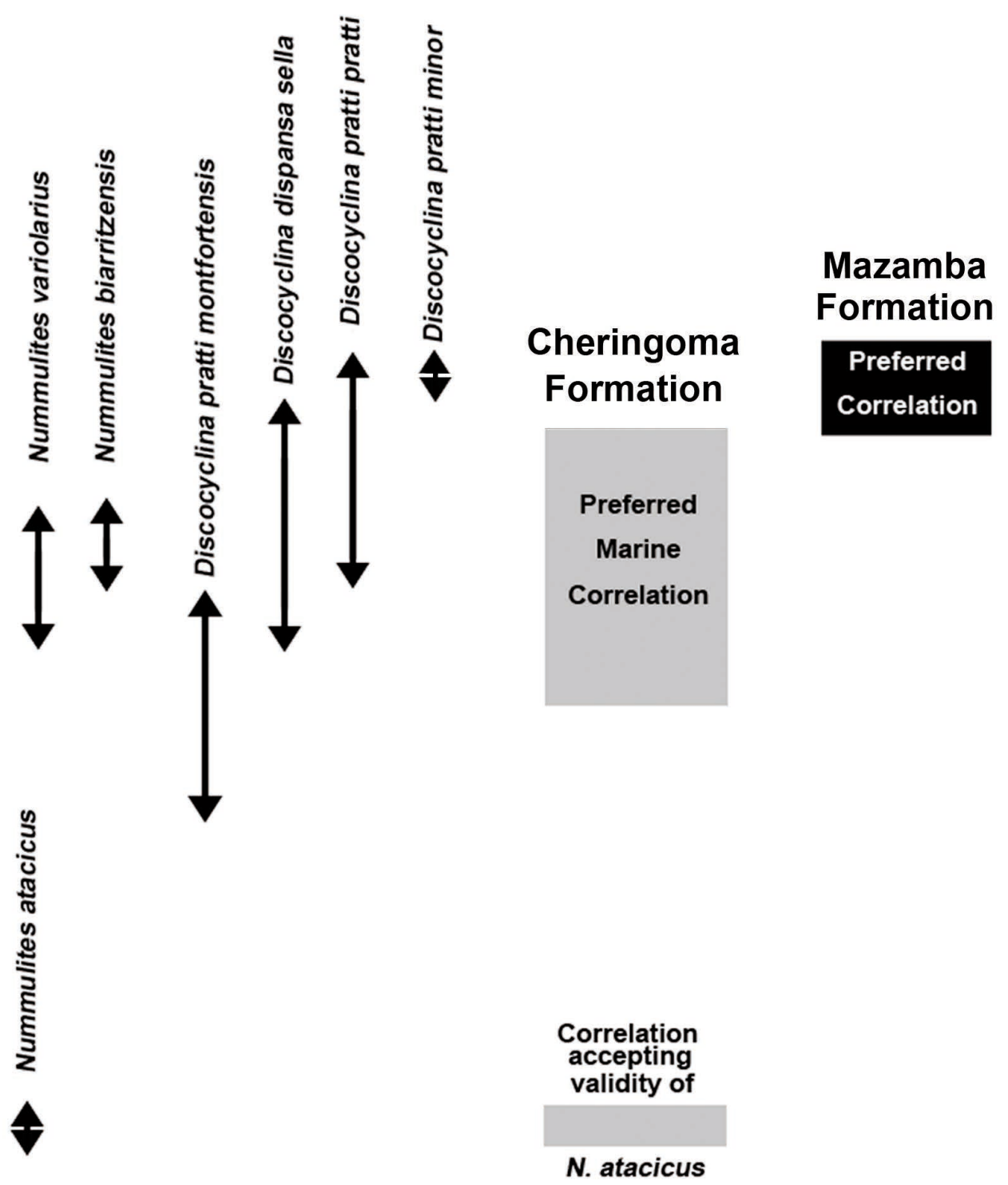

Text-fig. 6. Correlation of the Cheringoma and Mazamba formations on the basis of benthic foraminiferans and mammals respectively. Identifications of foraminiferans are from Newton (1924) and Abrard (1928), and the ranges of foraminiferans are from Sella-Kiel et al. (1998). The time scale is from Gradstein et al. (2020). The distribution of Nummulites atacicus is included, but it is not known whether it is reworked from older deposits. If the identification is valid, it would support the thesis that there was a period of Ypresian deposition in the vicinity during which remains of the species were fossilised. 
karst systems and created canyons and rock arches. Several remnants of rhyolites and nepheline basalts of Oligocene to Pliocene age occur on the Cheringoma Plateau forming distinct hills (Förster et al., 1982)". The age of karsification of the Cheringoma Formation is not as clear as this citation suggests. This appears to be the first report of rhyolite in the region. No evidence was provided in support of the correlations of the volcanic rocks, nor are the ages of the volcanic rocks reliably established.

Scoon (2016) summarised the geology of Gorongosa Park, but like the GTK Consortium (2006) and Grantham et al. (2011) before him, he inverted the stratigraphic order of the Mazamba and Inhaminga formations. The Mazamba Formation (spelled Mzamba by Scoon 2016: fig. 1) directly overlies the Cheringoma Formation, while the Inhaminga Formation, which used to be known as the upper member of the Mazamba Formation (Tinley 1977) overlies the Mazamba Formation in its restricted sense (i.e., the basal member of the Mazamba Fm in Tinley 1977). He reported that the Inhaminga and Mazamba formations were Miocene (23-5 Ma) and that these deposits were cut by a Pliocene (5.3-2.6 Ma) intrusive body of nepheline basalt "...on the crest of the Cheringoma Plateau". This is presumably a reference to the volcanics of the Gadjiua Hills of Tinley (1977) (called the N'Guere Hills by Real 1966).

Habermann et al. (2019) presented a geological map and section based largely on the compilation of Lächelt (2004) and they subdivided the Mazamba Formation into two units, a lower Mazamba Member and the overlying Inhaminga Member. They correctly inferred that "A review of the literature revealed inconsistencies in nomenclature and subdivision of this $<130 \mathrm{~m}$ thick succession (cf., Real, 1966; Tinley, 1977; Lächelt, 2004; GTK Consortium, 2006; Steinbruch, 2010; Grantham et al., 2011; Pickford, 2013). Based on Real (1966), Tinley (1977) refers to the succession as Mazamba Formation (see also Steinbruch, 2010; Pickford, 2013), attributes it to a Mio-Pliocene age, and subdivides the formation into a basal member of red sandstone and quartzitic limestone, a central chert unit, and an upper quartzitic and conglomeratic Inhaminga sandstone member. By contrast, the geological explanations produced by the GTK Consortium (2006) and Grantham et al. (2011) subdivide the succession into two separate formations, including the basal Inhaminga Formation, estimated to be of Miocene age, and the overlying Mazamba Formation, tentatively reaching a Pliocene age". Habermann et al. (2019) did not mention the presence of volcanic rocks in the Cheringoma Plateau area.

\section{Correlation of the Cheringoma Formation}

The shallow benthic foraminiferans from the Cheringoma Formation described by Newton (1924) and Abrard (1928) indicate a maximal age span from mid-Lutetian to early Priabonian according to the Shallow Benthic Zonation (SBZ) of Serra-Kiel et al. (1998), recalculated to the time scale of Gradstein et al. (2020) (Text-fig. 6). The precise locations and stratigraphic levels from which the described foraminiferan samples came are not known, so further controlled sampling is required, especially in the region of the Muaredzi Gorge close to the fossil mammal localities which are in the overlying Mazamba Formation. Provisionally therefore, we accept a late Bartonian to early Priabonian correlation for the summital layers of the Cheringoma Formation.

\section{Post-Cheringoma Formation sediments}

According to published geological maps of the Cheringoma Plateau, overlying the Cheringoma Formation there is a ca. 130-metre-thick succession of clastic rocks attributed herein to the Mazamba Formation and the Inhaminga Formation in that order (Real 1966, Tinley 1977, Pickford 2012, 2013, Habermann et al. 2019). Overlying these formations is a diversity of Pleistocene to Recent sediments (Real 1966, Tinley 1977). Tinley (1977) mapped occurrences of "chert" in the region north and north-east of the Nguere (Gadjiua) volcanic outcrops. They were reported to be older than the Inhaminga Formation, and were considered by Tinley (1977) to be silicified parts of the Cheringoma and Mazamba formations.

In the region surrounding Mhengere Hill and immediately north of the Muaredzi Gorge, the basal layers of the Mazamba Formation contain fossilised tree trunks, marine molluscs and mammals (Pickford 2013) as well as shark teeth (Habermann et al. 2019). The mammalian post-cranial bones noted by Pickford (2013) were identified as possibly representing seals, but appurtenance to Embrithopoda, Arsinoitheriidae is more likely (see below).

Habermann et al. (2019) listed a suid and a sivathere in the Mazamba Fm, but the supposed suid tooth does not belong to this family of mammals, and more likely represents an afrothere. The "sivathere" specimen was not illustrated and no further details are available in the literature (the authors have not seen the specimen). The partial shark tooth illustrated by Habermann et al. (2019) belongs to Galeocerdo, the Tiger Shark (F. Pfeil, 2020 pers. comm.). This genus ranges in age from Lutetian to Extant (Türtscher et al. 2021) but the form of the fossil tooth illustrated by Habermann et al. (2019) suggests that it does not belong to any of the species of this genus that are older than middle Lutetian. It is likely to be Priabonian or younger.

The oft reported presence of an unconformity between the Cheringoma and Mazamba formations is likely to be incorrect, at least in the region between the Muaredzi and Muanza rivers. The available geological maps provides no evidence of an unconformity, and reconnaissance examination of the outcrops in 2012 - 2013 did not show any evidence of a discordance. Thus, combining the reasonably secure correlation of the Cheringoma Formation to the late Lutetian-early Priabonian (Text-fig. 6) and the lack of an obvious discordant relationship with the overlying sediments, it is concluded that the basal Mazamba sediments most likely correlate to the lower or middle Priabonian (ca. 38.5-35 Ma) (Text-fig. 6). Clearly, a more comprehensive and more diverse palaeontological sample and detailed geological mapping is required to yield more precise estimates of the time period spanned by the sediments of the Mazamba Formation, but continued retention of a purely Miocene correlation appears to be untenable, as explained above. It is possible that the sediments at Muaredzi currently attributed to the Mazamba Formation need to be subdivided into a basal unit of late Eocene age, and an overlying Oligo- 
Miocene deposit. The only way of resolving the uncertainty is detailed remapping and palaeontological survey.

\section{Volcanics of the Cheringoma Plateau}

One of the first mentions of the presence of volcanic rocks in the Cheringoma Plateau was by Teale (1924) who wrote that they form "the Nkweri Hills which rise above the Eocene limestone. The beds close to the contact are mainly grits and are again indurated. This is almost certainly a post-Eocene intrusion". Note the element of doubt about the intrusive nature of the basalts expressed in this citation. No direct proof of the intrusive nature of the basalts has been proffered and it is not beyond the realms of possibility that they may predate the Cheringoma Limestone, in which case they might represent a basaltic sea-mount buried by marine limestones and grits, and subsequently re-exposed by erosion. Closer field observations are required to resolve the matter.

According to Real (1966) the volcanic outcrops at N'Guere intruded through the Cheringoma Formation (i.e., the limestones) (the hills were called Inkweyri by Thiele and Wilson 1915, Nkweri by Teale 1924, Inkweri by Mennel 1929, Nguére by Ferrara et al. 2006, and Gadjiua by Tinley 1977). As a place name in agricultural areas of Africa, N'Guere, and variants of the word (Gengere - Nigeria, Uganda; Ngerngerwa - Kenya; Ngerngeranjuch - Kenya) signifies stony ground or rocky soil, and this could well be the case for Mhengere, which is also a rocky area.

Teale (1924) inferred that the basalts must be post-Eocene, and subsequently ages of Bartonian-Priabonian (Lächelt 2004), Oligocene and Pliocene (Steinbruch 2010) have been proposed. Flores (1973: 84, fig. 1) mapped two "Tertiary necks" on the Cheringoma Plateau. Tinley (1977) inferred that the basalts cut through the Mazamba Formation (his $\mathrm{TTs}_{1}$ ) in agreement with the observation of Teale (1924) that the beds close to the contact are indurated grits, but the relationship to the Inhaminga Member (his $\mathrm{TTs}_{2}$ ) is not preserved. On the assumption that the Mazamba Formation was Miocene, Tinley (1977) proposed a Pliocene age for the basalts.

The Nguére Hills are marked on the Geological Map Sheet 1834 compiled by Ferrara and Manninen (2006) but they are mapped as $\mathrm{Te}_{1}$ (Inhaminga Formation). No mention of the volcanic nature of these hills appears on the map. In the same map, Mhengere Hill is clearly depicted above the $100 \mathrm{~m}$ contour line $2.5 \mathrm{~km}$ north of the Muaredzi (Muredze) gorge, but it is not named.

In Real's (1966) map, the small "lava" outcrop $23 \mathrm{~km}$ west-south-west of N'Guere turns out to correspond to Mhengere Hill, and is thus not lava at all (Pickford 2012, 2013). Real (1966) called it olivine basalt. Tinley (1977) plotted two outcrops of basalt on his map, citing Real (1966), one corresponding to what he called the Gadjiua Hills and

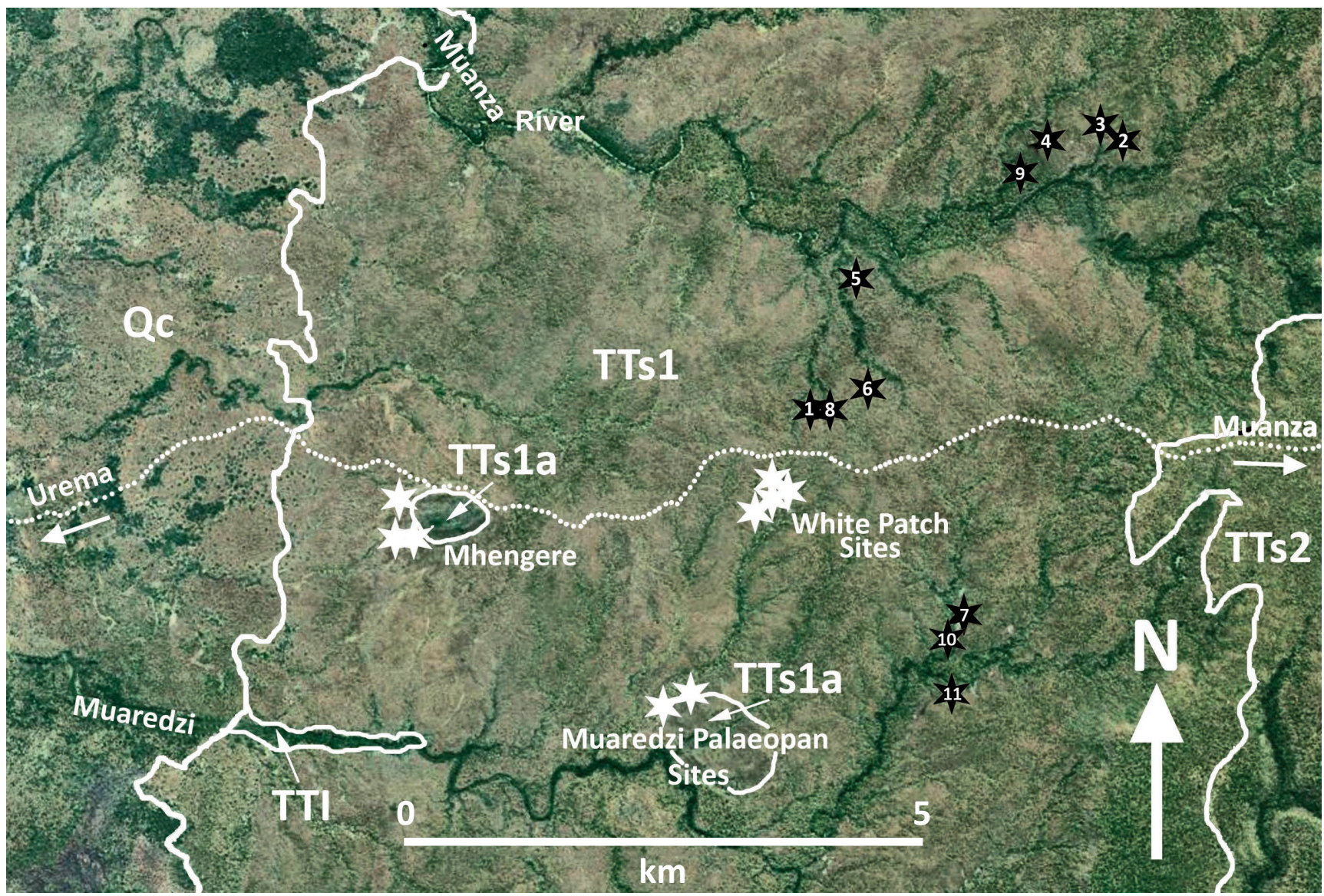

Text-fig. 7. Geology of the Muaredzi-Muanza sector of the Cheringoma Plateau showing the location of fossil occurrences. White stars - fossiliferous localities mapped by Pickford (2012, 2013), Black stars - fossil sites mapped by Habermann et al. (2019) and d'Oliveira Coelho et al. (2021) (GPL 12 and GPL 12b correspond to the White Patch sites). TTI - Cheringoma Formation, TTs1 Mazamba Formation, TTs1a - Palaeopan facies, TTs2 - Inhaminga Formation, Qc - Quaternary sediments. The base map is modified from Google Earth. 
the other to Mhengere, but he put the latter outcrop in the wrong place (about $6 \mathrm{~km}$ east of the Mhengere outcrop as shown in Real (1966).

Lächelt (2004: tab. 5.26) listed augite, limburgite, nepheline and olivine basalt at Inhaminga and estimated their ages as Miocene-Pliocene. This listing presumably refers to the Nguere Hills.

To complicate matters, Steinbruch (2010) cited Förster et al. (1982) concerning the ages of the Cheringoma volcanics as Oligocene and Pliocene and the composition of the lavas was enlarged to include rhyolite as well as nepheline basalt. However, examination of the map prepared by Förster et al. (1982) reveals no mention of Tertiary volcanic rocks in the Cheringoma Plateau. Indeed the map does not include the Cheringoma region.

All that can be said at the moment about the age of the volcanic rocks comprising the Nguere Hills is that they may be post-Priabonian, because they seem to have intruded through basal sediments of what has been mapped as the Mazamba Formation but this possibility needs to be tested by ground surveys and by radio-isotopic age analyses, because there is a possibility that the lavas predate the sediments.

\section{New observations and discussion}

The stratigraphic succession of the Cheringoma Plateau in the country between the Muaredzi and Muanza rivers (Text- fig. 7) needs to be re-surveyed in detail because the strata that have been mapped as the Mazamba Formation, most likely accumulated during the late Bartonian - early Priabonian. It is hypothesised that as sea level dropped at the end of deposition of the Cheringoma Limestone (late Bartonian) there was an eastwards (oceanwards) shift of sedimentary depositional facies, such that the Cheringoma area was successively subjected to shallow marine, lagoonal, deltaic and onland fluvio-palustral sedimentation, most likely without a major temporal break in sedimentation (Lächelt 2004, Pfaffhuber et al. 2009). This would mean that the Mazamba Formation to which these shallow marine, lagoonal, deltaic and fluviopalustral deposits are assigned, would be substantially older than the latest Eocene or early Oligocene (late Priabonian Rupelian), and would thus have accumulated prior to deposition of the Fayum succession, Egypt (ca. $34 \mathrm{Ma}$; Seiffert 2010). If the presence of a small embrithopod in the Mazamba Fomation is correct, then this would also indicate a pre-Fayum age (Sanders et al. 2010). This discovery indicates that the traditional, oft-repeated, correlation of the Mazamba Formation to the Miocene and/or Pliocene (Real 1966, Tinley 1977, Habermann et al. 2019) is likely to be incorrect, at least in the country between the Muaredzi and Muanza rivers.

However, as it presently stands, parts of the Muaredzi-Muanza sector of the Cheringoma Plateau are topographically low enough $(80-120 \mathrm{~m}$ asl) to have been transgressed during the Aquitanian-Burdigalian high sea

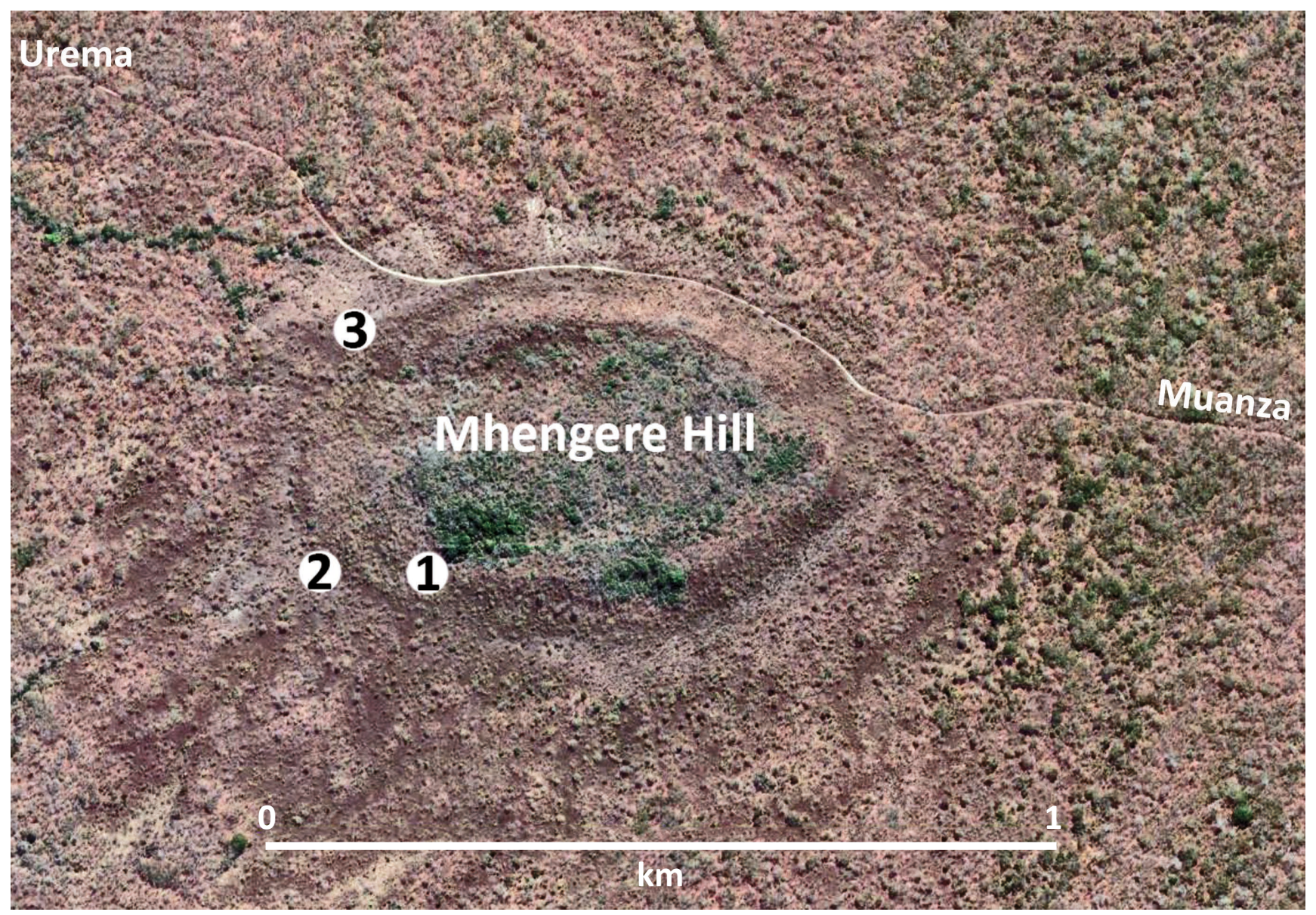

Text-fig. 8. Mhengere Hill fossiliferous localities (1-3). Silicified tree trunks and fragments of wood are abundant in the poorly indurated basal deposits (marly sand and conglomerate) as well as in the silicified lime-rich sandstones that form the hill, which is interpreted to be the remains of a palaeopan. Image modified from Google Earth. 
Table 5. GPS coordinates and approximate altitudes of palaeontological sites in Gorongosa studied in November, 2013 (WGS 84 datum).

\begin{tabular}{|l|c|c|c|c|}
\hline \multicolumn{1}{|c|}{ Locality } & Latitude & Longitude & Altitude (from GPS) & Content \\
\hline Mhengere Wood 1 & $18^{\circ} 56^{\prime} 15.5^{\prime \prime} \mathrm{S}$ & $34^{\circ} 36^{\prime} 53.9^{\prime \prime} \mathrm{E}$ & $119 \mathrm{~m}$ & Wood \\
\hline Mhengere Wood 2 & $18^{\circ} 56^{\prime} 16.2^{\prime \prime} \mathrm{S}$ & $34^{\circ} 36^{\prime} 49.9^{\prime \prime} \mathrm{E}$ & $109 \mathrm{~m}$ & Wood \\
\hline Mhengere Wood 3 & $18^{\circ} 56^{\prime} 05.5^{\prime \prime} \mathrm{S}$ & $34^{\circ} 36^{\prime} 52.0^{\prime \prime} \mathrm{E}$ & $96 \mathrm{~m}$ & Wood \\
\hline Muaredzi Hill 2 Wood 4 & $18^{\circ} 57^{\prime} 04.3^{\prime \prime} \mathrm{S}$ & $34^{\circ} 38^{\prime} 14.0^{\prime \prime} \mathrm{E}$ & $78 \mathrm{~m}$ & Wood \\
\hline Muaredzi Hill 2 Wood 5 & $18^{\circ} 57^{\prime} 12.9^{\prime \prime} \mathrm{S}$ & $34^{\circ} 38^{\prime} 09.6^{\prime \prime} \mathrm{E}$ & $91 \mathrm{~m}$ & Wood \\
\hline White Patch Snails 1 & $18^{\circ} 56^{\prime} 14.6^{\prime \prime} \mathrm{S}$ & $34^{\circ} 38^{\prime} 40.8^{\prime \prime} \mathrm{E}$ & $113 \mathrm{~m}$ & Marine molluscs \\
\hline White Patch Bones & $18^{\circ} 56^{\prime} 10.9^{\prime \prime} \mathrm{S}$ & $34^{\circ} 38^{\prime} 41.0^{\prime \prime} \mathrm{E}$ & $105 \mathrm{~m}$ & Mammal \\
\hline White Patch 1 Turritella Site & $18^{\circ} 56^{\prime} 06.1^{\prime \prime} \mathrm{S}$ & $34^{\circ} 38^{\prime} 45.4^{\prime \prime} \mathrm{E}$ & $100 \mathrm{~m}$ & Marine snails \\
\hline White Patch 2 Bone Site & $18^{\circ} 56^{\prime} 11.8^{\prime \prime} \mathrm{S}$ & $34^{\circ} 38^{\prime} 46.4^{\prime \prime} \mathrm{E}$ & $101 \mathrm{~m}$ & Mammal \\
\hline
\end{tabular}

stands which are known to have been 90-100 metres above present-day sea level (Pickford 1998). However, being at the southern extremity of the African Rift System, the Urema Rift and Cheringoma Plateau have undoubtedly experienced vertical earth movements since the early Miocene, which complicates understanding of their topographic, erosional and depositional histories. The region is still seismically active (Steinbruch 2010).

Up to now, no convincing evidence of the presence of Miocene fossils has been demonstrated to occur in this sector, the marine invertebrates that have so far been found being undiagnostic of age. The partial shark tooth (Galeocerdo) illustrated by Habermann et al. (2019) could provide support for an age no older than the Miocene, but more complete material is required to provide a secure conclusion. If Miocene deposits are indeed present in the MuaredziMuanza sector, then it would appear that the Mazamba Formation, as currently mapped, may be a composite of late Eocene and early Miocene deposits.

\section{Palaeopans and fossils}

The palaeontological localities discovered in the vicinity of Mhengere Hill in 2013 (Tab. 5) are located within lime-rich clayey sands and conglomerates of the Mazamba Formation as well as in oval outcrops of sandy limestones that have been silicified to chert facies near the top. The latter deposits

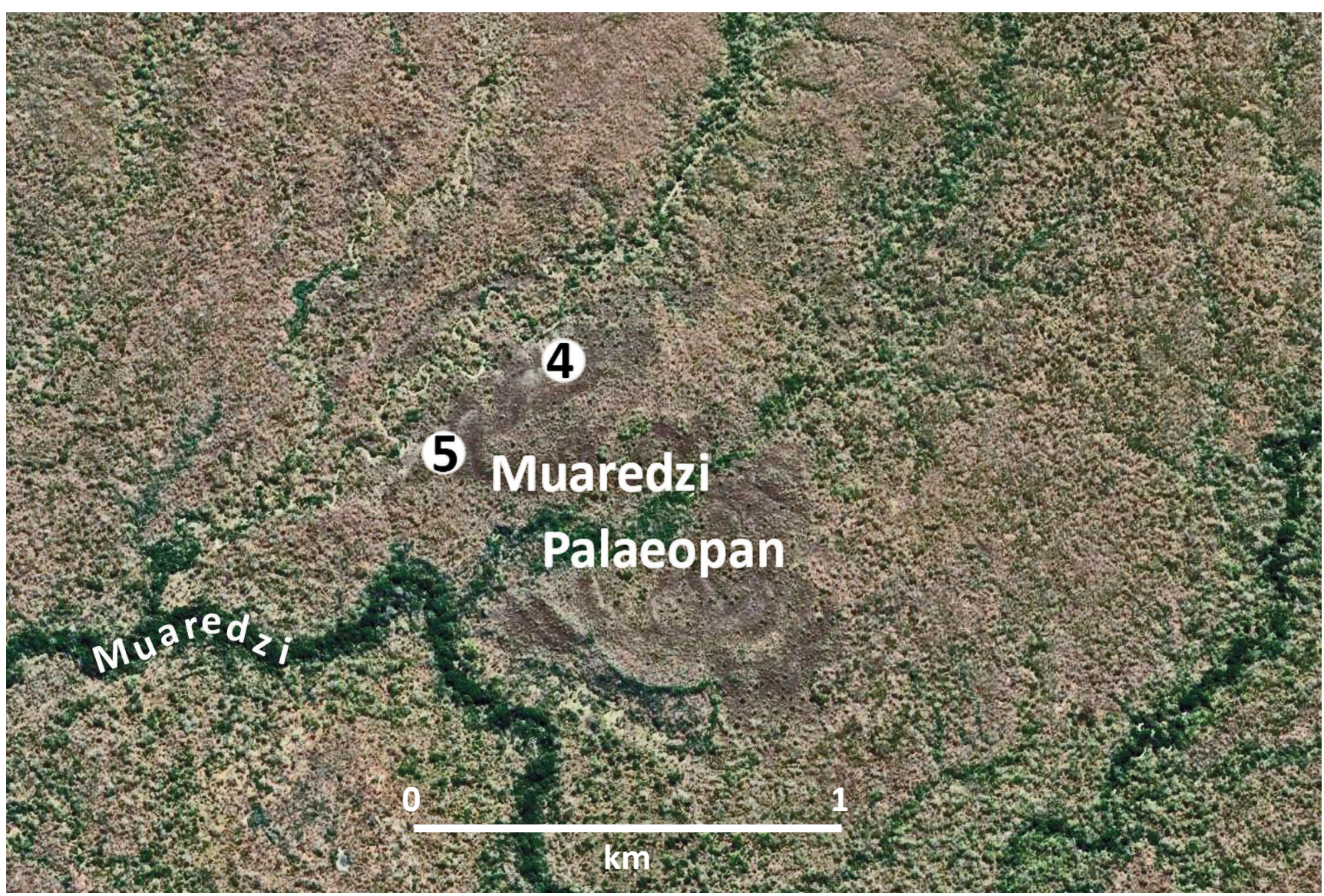

Text-fig. 9. Fossil wood localities 4 and 5 close to the palaeopan on the north flank of the Muaredzi Gorge. Image modified from Google Earth. 


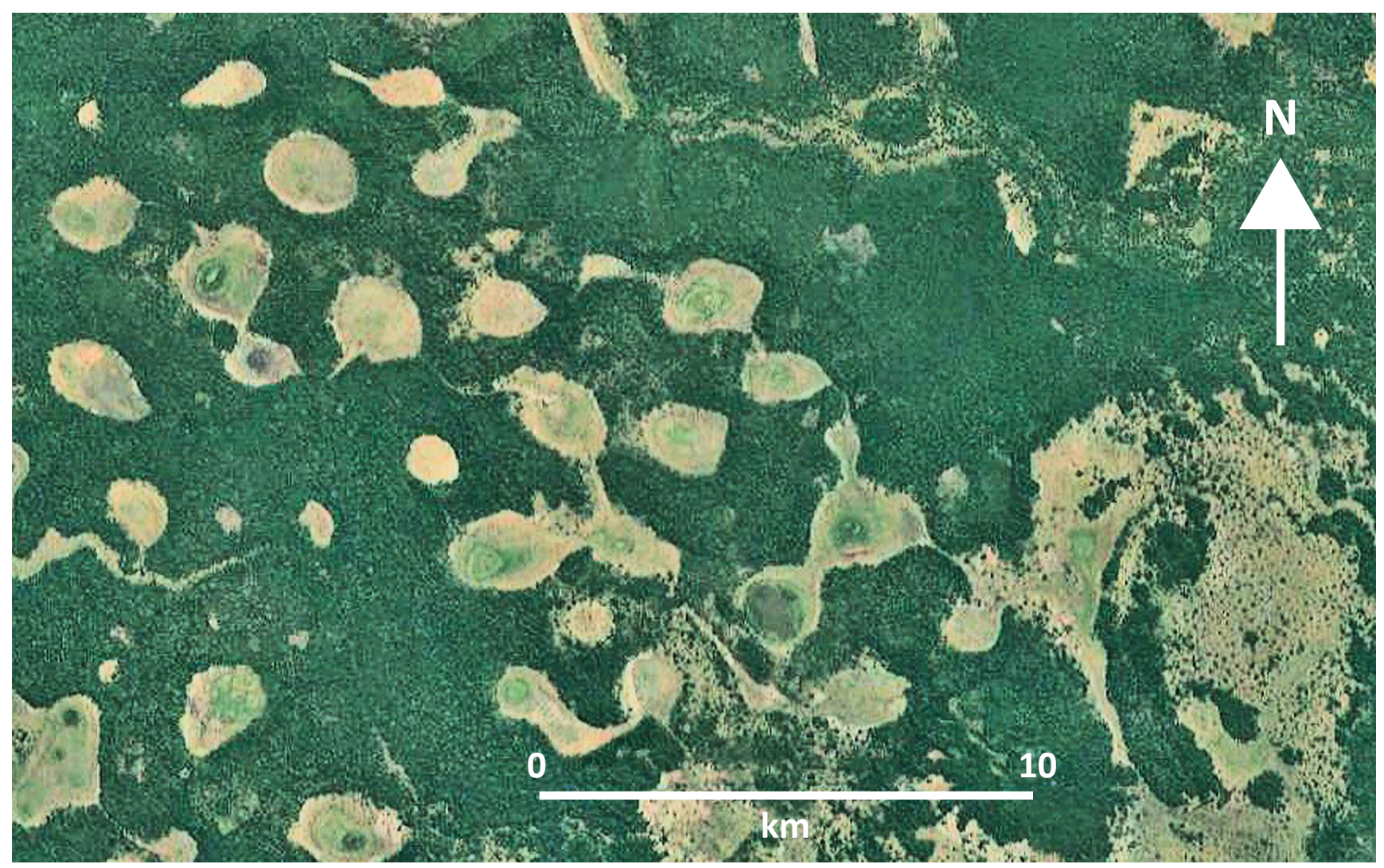

Text-fig. 10. Extant pans east of Inhaminga $\left(1^{\circ} 26^{\prime} 28^{\prime \prime}\right.$ 'S : 35 $\left.35^{\prime} 45^{\prime \prime} E\right)$ surrounded by woodland. The pans typically have an arid, vegetation-free, marginal zone and a water-logged sump. Some pans are connected to each other by shallow overflow valleys. Image modified from Google Earth.

(TTs1a in Text-fig. 7) are more resistant to erosion than the less consolidated sediments of the Mazamba and Inhaminga formations which explains why they form positive relief features in the landscape (Text-figs 8,9). In their form and dimensions (up to a kilometre in greatest diameter), these oval outcrops resemble the multitudes of pans that occur in the lowlands 50-70 km east of Inhaminga (Text-fig. 10) and this is probably what they originally looked like prior to being silicified and then eroded.

The remains of the two palaeopans at Mhengere (Textfig. 8) and Muaredzi (Text-fig. 9) are ovoid in plan with slightly concave upper surfaces. They show a concentric arrangement of layers. The larger of the two is $1 \mathrm{~km}$ in greatest diameter by $0.5 \mathrm{~km}$ broad. The sediments exposed on the sides and tops of the two hills comprise clays, sands, carbonates and layers that have been altered to chert. Suncracks are common in the sediments.

At present, hundreds of pans occur $70 \mathrm{~km}$ east of Inhaminga between 30 and 150 metres above sea level. Most of them are ovoid in outline and they range up to $2 \mathrm{~km}$ in greatest diameter (Text-fig. 10). Typically, they are surrounded by woodland, and consist of an outer vegetationfree marginal zone which is usually dry except after rains. The sumps of many of the pans are permanently to semipermanently water-logged with lightly vegetated zones between the sumps and the dry marginal zones. The relief in the pans is of the order of 5-6 metres in the larger examples. The margins of the pan dry out by evaporation which often leads to the formation of a hard crust overlying softer, damp sediments. Suncracks are a common byproduct of the dessication. If dessication is repeated many times, these crusts can become indurated by carbonates or silica.

In most of these details, the two ovoid outcrops at Mhengere and Muaredzi conform with extant pans, and they are thus interpreted to be the remains of an ancient system of pans that have lost some of the marginal facies by erosion.

\section{Systematic palaeobotany}

During a reconnaissance trip in November 2013 to Gorongosa National Park, central Mozambique, a large silicified tree trunk and several scattered pieces of wood were discovered and collected from Mhengere Hill and Muaredzi Palaeopan (Text-figs 11-13) (Pickford 2013). The large trunk is clearly a palm tree because the adventitious roots as well as large vascular bundles in the cortex are visible to the naked eye. It is similar to extant Hyphaene spp. and is attributed to Palmoxylon dutoitii. Smaller pieces of silicified woods from the same areas belong to hardwoods. One sample belongs to the Anacardiaceae and is similar to the extant Sorindeia madagascariensis, so the fossil wood is named Sorindeioxylon gorongosense gen. et sp. nov. The rest of the samples belong to the Combretaceae, and are called Terminalioxylon mozambicense sp. nov. Palms (Hyphaene) occur in the Cheringoma region today as do hardwoods. They suggest an environmental setting with high groundwater levels, a warm frost-free environment and moderate to high rainfall. A waterhole setting in a humid environment is proposed for the fossil deposit. 


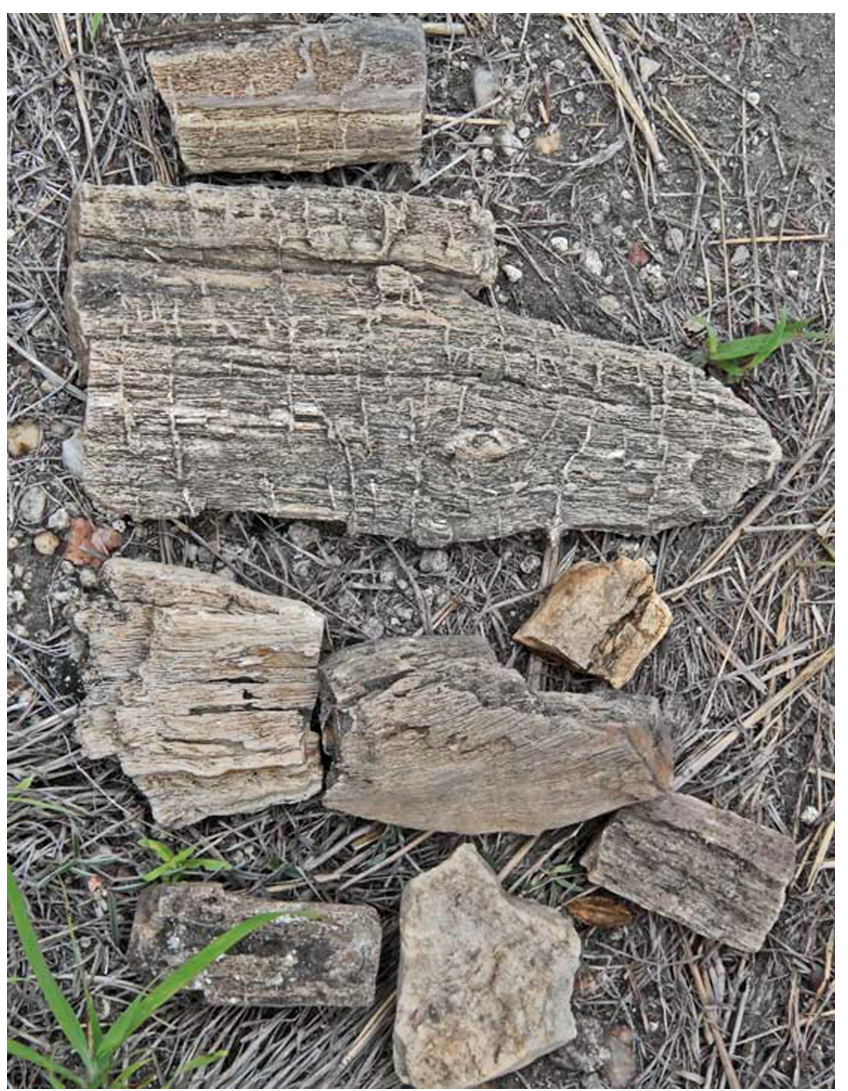

Text-fig. 11. Silicified hardwood fragments from Mhengere Wood Site 2. The longest piece is $16 \mathrm{~cm}$ long (image by MP).

\section{Modern vegetation}

Today the Cheringoma region is covered with typical savanna grassland vegetation with $\mathrm{C} 4$ grasses and Miombo woodland trees such as Combretum adenogonium, Diplorhynchus condylocarpon and Philenoptera violacea. The Mhengere hilltop and the valley are more densely wooded than the hill slopes where the fossil woods were found. A large section of silicified trunk almost $1 \mathrm{~m}$ in diameter and $1 \mathrm{~m}$ long, associated with a number of fractured pieces, was exposed on the slope partly hidden by tall grasses (Text-figs 11, 12, 13a). Further searches revealed a number of much smaller pieces of silicified woods eroding down the slope.

\section{Material and methods}

Nine pieces of silicified wood were collected by MP and delivered to South Africa for sectioning and study at the Evolutionary Studies Institute, University of the Witwatersrand, Johannesburg. Preliminary identifications of the woods were presented in an unpublished report (Bamford in Pickford 2013). Detailed descriptions and comparisons with other fossil woods are provided here.

Eight of the small pieces of silicified wood were sectioned in three planes, transverse (TS), radial longitudinal (RLS) and tangential longitudinal (TLS), polished, mounted on glass slides and ground and polished to a thickness of about $40 \mu \mathrm{m}$ in the standard manner for thin sections. A Zeiss Axiophot petrographic microscope and Olympus DP72 digital camera with Stream Essentials ${ }^{\circledR}$ software were used to study, measure and photograph the thin sections. Identification of the woods was done using the
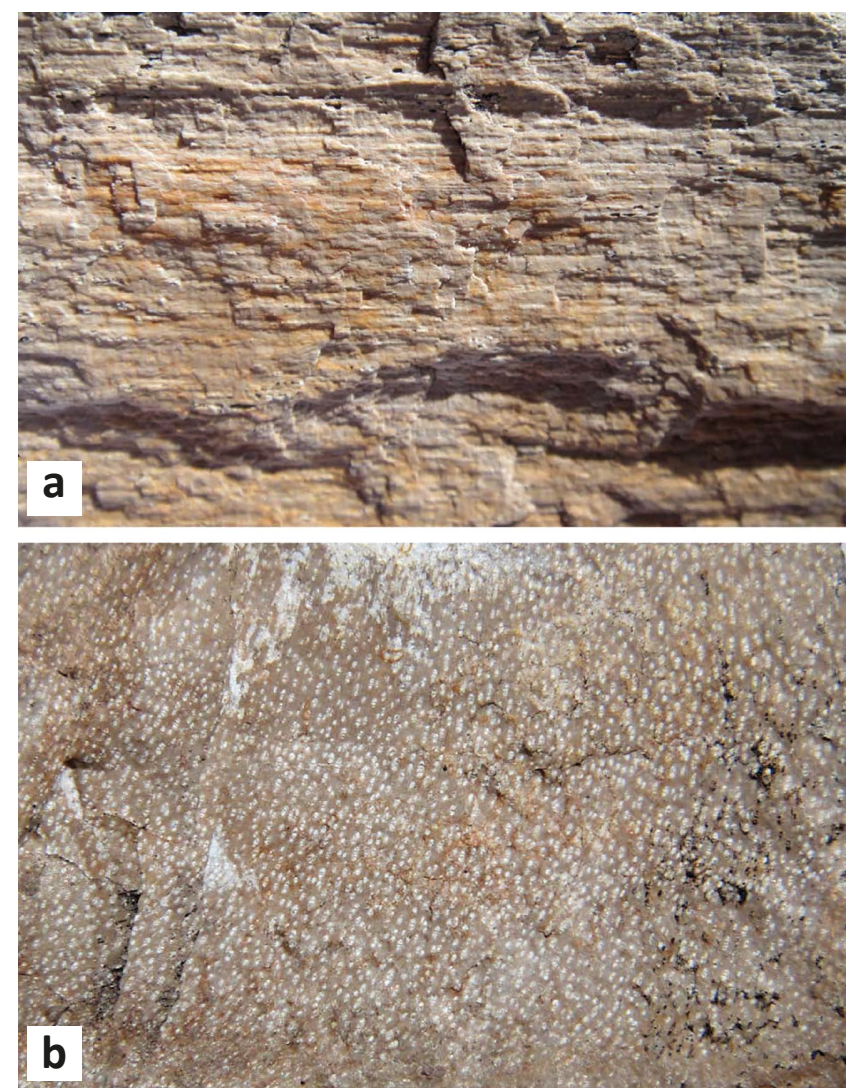

Text-fig. 12. Close-up views of silicified stem from Mhengere Fossil Wood Site 2. a: natural longitudinal fracture surface; b: natural cross section (images by MP).

IAWA Committee (1989) Hardwood terminology and the InsideWood online database (http://insidewood.ncsu) for modern and fossil woods. Terminology for the palm stem follows that of the literature cited below. Growth habits and habitats for the species were obtained from a number of published field guides and floras as listed where relevant. The order of description is monocot then dicot. The dicots are presented alphabetically by Family.

New names of fossil plants are registered in the Plant Fossil Names Registry, which is hosted and operated by the National Museum, Prague for the International Organisation of Palaeobotany (IOP), each with a unique PFN number.

Family Arecaceae BerCht. et J.Presl, 1820 nom. cons. Subfamily Coryphoideae BurnetT, 1835

Tribe Borasseae MART. in Endlicher 1837 Subtribes Hyphaeninae BECc., 1924 or Lataniinae MeISN., 1842

Modern gen era. Hyphaene GAERTN., Borassus L.

\section{Genus Palmoxylon Schenk, 1882}

Ty p e. Palmoxylon blanfordii ScHENK, 1882.

\section{Palmoxylon dutoitii KaUL, 1945}

Text-figs 13,14

Specimen. BP/16/1732 (slides and stem samples housed in the Palaeobotany Herbarium, Evolutionary Studies Institute, University of the Witwatersrand, Johannesburg). 

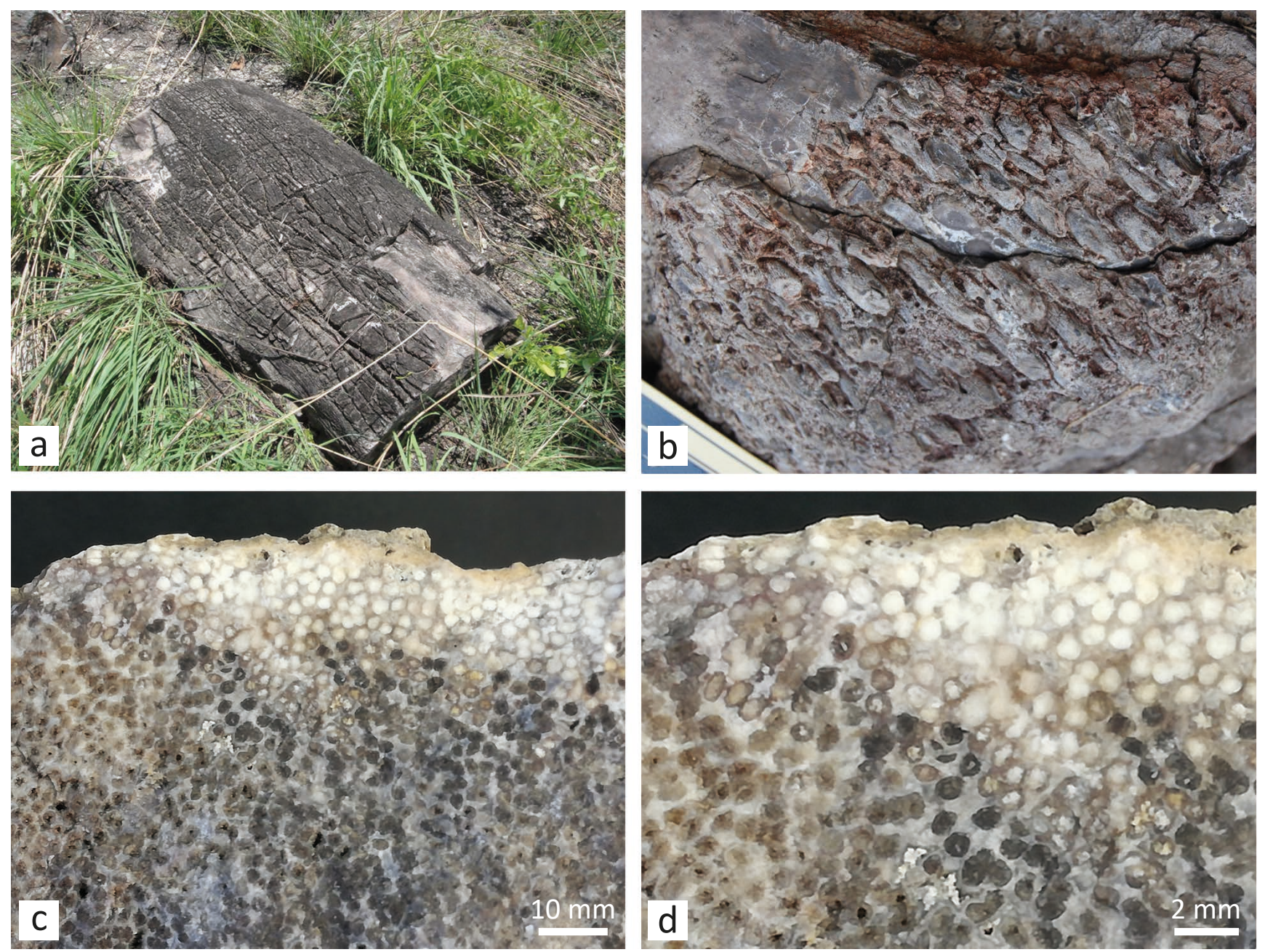

Text-fig. 13. Macrophotographs of the fossil stems from Mhengere. a: large $(90 \mathrm{~cm}$ diameter) palm tree trunk in situ; b: external view of the outer roots at the base of the trunk; average diameter of single root is $7 \mathrm{~mm}$; c, d: cross-sections of a fragment of trunk showing the random distribution of equal-sized fibre vascular bundles throughout the trunk, the so-called Coccos-type.

L o c a lity. Site 3, lower slopes on northwest side of Mhengere Hill, Gorongosa National Park, Mozambique (Text-fig. 8).

Description and comparisons. There is one large trunk, about $90 \mathrm{~cm}$ in diameter lying on the side of the hill (Text-fig. 13a) accompanied by scattered fragments close by and farther down the hillside. Natural sections in broken specimens are easy to recognise by the regular arrangement of the large vascular bundles. Photomicrographs of the palm stem and an annotated drawing of a fibrovascular bundle (fvb) are presented in Text-fig. 14.

The distribution of the fibre vascular bundles in the parenchymatous cortex is random and the bundles are more or less the same size throughout the cortex, the socalled Coccos-type (Dransfield et al. 2005). Parenchyma is poorly preserved but appears to be homocellular with uniform and compact parenchyma cells (Text-fig. 13c, d). A few parenchyma cells appear to have thicker walls so are interpreted to be lignified (Thomas and De Franceschi 2013). Diameters of the fibre vascular bundles range from $1,000 \mu \mathrm{m}$ to $1,160 \mu \mathrm{m}(1.0-1.16 \mathrm{~mm})$ and they are round to sub-round in cross-sectional shape (Text-fig. 14a-f).

Each fibre vascular bundle is composed of a fibrous part and a vascular part, with the reniform fibrous part surrounded by a thin layer of tabular parenchyma. The much smaller vascular part has an inner metaphloem region that tends to break down and leaves an empty patch. Within the paravascular parenchyma are mostly two large metaxylem elements (sometimes three) adjacent to each other with an average diameter of $116 \mu \mathrm{m}$, and external to these are one to two small protoxylem elements. The vascular section is surrounded by a narrow sheath of parenchyma that appears to merge with the parafibrous sheath.

Parenchyma between the fibre vascular bundles is poorly preserved but appears to be compact and homogeneous (Text-fig. 14a). In longitudinal section (Text-fig. 14g, h) the metaxylem elements have horizontal thickenings. The fibres are poorly preserved. There are only a few patches of intact parenchyma cells and they are rounded to slightly elongated. Parenchyma cells with darker and thicker cell walls that may be lignified occur throughout the stem. Scattered throughout the section are globular echinate phytoliths (Text-fig. 14).

Identification. The simple and collateral bundles distributed throughout the stem with a parenchymatous ground tissue are typical of the Arecaceae. The even distribution, or Coccos-type, of fibre vascular bundles throughout the cortex occurs in the Coryphoideae and a few of the Arecoideae, and reniform fibre vascular bundles 

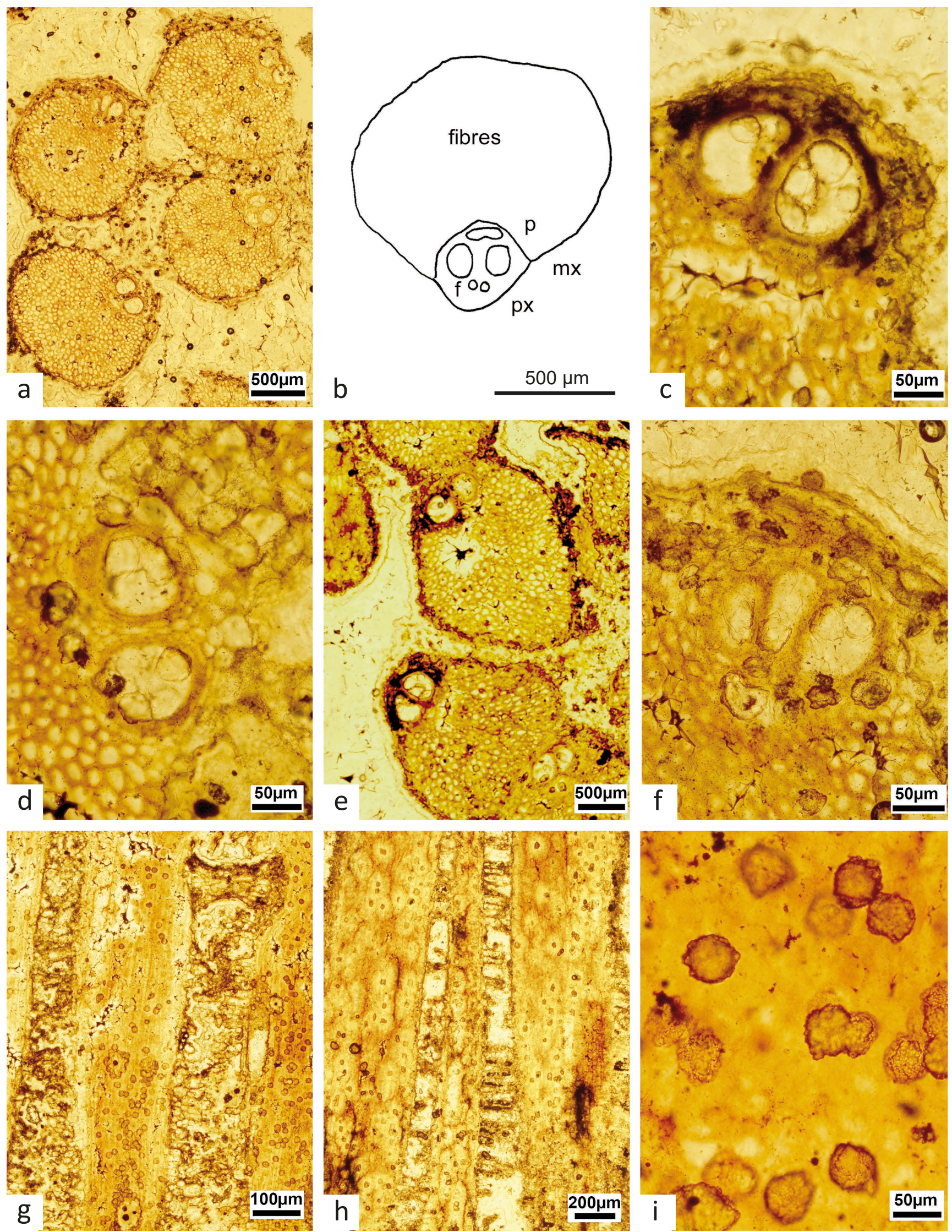

Text-fig. 14. Photomicrographs of thin sections of specimen BP/16/1732 Palmoxylon dutoitii from Mhengere Hill, Gorongosa, Mozambique. a: transverse section (TS) with four fibre vascular bundles (fvb) and poorly preserved parenchyma between; b: diagram of one of the fvbs in (a) of the reniform type (f - fibres, $\mathbf{m x}$ - metaxylum, $p$ - phloem, px - protoxylum); c: close up of the vascular part of a fvb with 2 metaxylem elements and the collapsed cells to the lower left represents the phloem; d: fvb with 2 metaxylem elements, fibrous part to the left and parencymarous ground tissue to the right; e: lower magnification of fvb in (c); f: fvb with three metaxylem elements and phloem patch below; g: longitudinal section (LS) showing the vascular sections alternating with the fibrous sections; $h$ : LS showing the horizontal thickening on the walls of the metaxylem vessels and a patch of parenchyma to the right (darker cells); i: spheroid echinate phytoliths that are typical of Hyphaene and Borassus. 
are typical of the Borasseae (Thomas and de Franceschi 2013). The two subtribes of the Borasseae (Lataniinae and Hyphaeninae) can be separated by the occurrence of two (to three) metaxylem elements and spheroid, compact ground tissue parenchyma in the Hyphaeninae, while the Lataniinae have only one metaxylem element per fibre vascular bundle and the ground tissue is composed of an irregular network of rhombohedral to lobed cells. The fossil palm, therefore, is a member of the Hyphaeninae, in which there are two extant genera, Borassus and Hyphaene.

Although Nypa and Sabal have the same type of vascular bundles, they are unlike the Mhengere Hill specimen. Nypa fruticans has a prostrate stem, up to $45 \mathrm{~cm}$ in diameter (Burkhill 1997) whereas the fossil stem described herein is $90 \mathrm{~cm}$ in diameter and from a tall, straight trunk. Sabal does not occur in Africa and it has no fossil record (Pan et al. 2006); the extant species of the genus occur in the Americas.

There are several classifications of the palms (Palmae Juss. / Arecaceae Bercht. et J.Presl) (see review in Baker and Dransfield 2016), but we have selected to follow one that takes stem anatomy into account. According to the classification of the Arecaceae (Baker and Dransfield 2016) there are five recognised subfamilies, one of which is the Coryphoideae that encompasses eight tribes. Compared with other tropical regions, the diversity of palms in Africa is low (Uhl and Dransfield 1987) and is meagre in southern Africa with only Phoeniceae and Borasseae present. In this region there are eight native species (Klopper et al. 2006, van Wyk and van Wyk 2013, Burroughs et al. 2018) in three genera: Phoenix, Hyphaene and Borassus.

The Mhengere Hill fossil stem is most similar to Hyphaeninae based on the structure and distribution of the fibre vascular bundles but without well-preserved ground tissue, it is not possible to determine which extant genus is the most similar.

Fossil Arecaceae in Africa are represented from the Aptian to the Pleistocene by fruits, leaves, petioles, pollen and stems (Vaudois-Miéja and Lejal-Nicole 1987, SalardCheboldaeff and Dejax 1991; see reviews in Harley 2006, Pan et al. 2006, Nour-El-Deen et al. 2018). Fossil stems are usually ascribed to Palmoxylon and about 23 species have been described to date, the majority from Egypt, some from other countries in North Africa and one species from South Africa (Kaul 1945, Nour-El-Deen et al. 2018). Slides of Palmoxylon dutoitii (Kaul 1945) were described based on material collected by Alex du Toit from river gravels of the Vaal River near Barkly West. According to du Toit (1929) the deposit is probably Tertiary in age. P. dutoitii has the Coccos-type regular distribution of reniform fibre vascular bundles. Each bundle has 2(-3) metaxylem elements and a dense fibrous cap. The ground tissue is composed of wellpreserved, spherical, compact parenchyma cells. Without any additional features, the Gorongosa fossil stem is considered to represent the same species as the Barkly West stem from South Africa.

Palms are restricted to tropical areas and most species do not tolerate frost (Tomlinson 2006). Hyphaene and Borassus are mainly African taxa and all require a high water table, so they occur along water courses or in floodplains, in more arid areas in the case of Hyphaene thebaica and Hyphaene compressa, or in moister but not wet areas in the case of
Hyphaene coriacea, Hyphaene petersiana, Hyphaene crinita and Borassus aethiopum (Dransfield 1986, Beentje 1994, Arbonnier 2002, van Wyk and van Wyk 2013). Palmoxylon dutoitii, therefore, indicates a local environment with a high water table, frost-free climate suitable for the sustained growth of large trees (based on the large diameter of the trunk).

\section{Family Anacardiaceae R.BR., 1818 nom. cons.}

\section{Genus Sorindeioxylon gen. nov.}

Ty p e. Sorindeioxylon gorongosense sp. nov.

Plant Fossil Names Registry Number. PFN002685 (for new genus).

Etymology. Combination of the extant genus Sorindeia with suffix xylon meaning wood.

D i a $\mathrm{n}$ o s is. As for the species.

\section{Sorindeioxylon gorongosense sp. nov.} Text-fig. 15

Holotype. BP/16/1738 - three slides and the remaining piece of wood (Text-fig. 15).

Plant Fossil Names Registry Number. PFN002686 (for new species).

R e p o s i t o r y. Curated at the Palaeobotany Herbarium, Evolutionary Studies Institute (previously the Bernard Price Institute), University of the Witwatersrand, Johannesburg, South Africa.

Ety mology. The species name refers to Gorongosa National Park with the Latin suffix ense meaning "from".

Type locality. Muaredzi Site $5\left(18^{\circ} 56^{\prime} 02.0^{\prime \prime} \mathrm{S}\right.$, $\left.34^{\circ} 36^{\prime} 50.6^{\prime \prime} \mathrm{E}\right)$ fossil wood associated with palaeopan, northwest side. Mazamba Formation (Text-fig. 9), probably late Eocene.

Diagnosis. Diffuse porous dicotyledonous wood with indistinct to absent growth rings. Vessels round, solitary or in pairs, tangential diameter $50-100 \mu \mathrm{m}$ and less than 5 vessels per square $\mathrm{mm}$. Perforation plates are simple. Intervessel and vessel-ray pits are the same, alternately arranged and $6-8 \mu \mathrm{m}$ in diameter. Apotracheal parenchyma in narrow terminal or initial bands. Paratracheal parenchyma is vasicentric to rarely aliform. Rays are low, uni- to triseriate with the uniseriate sections as wide as the triseriate sections, heterocellular with mixed procumbent, square and upright cells. Prismatic crystals occur in the upright and square ray cells.

Closest extant tax on. Sorindeia madagascariensis THOUARS ex DC.

$\mathrm{D}$ e s c r i p t i o n. Growth rings are not visible in the thin section and the wood is diffuse porous. There are narrow bands of parenchyma, up to three cells wide, and randomly distributed. Vessels are round and 1, rarely 2 cells in short radial multiples. The average radial and tangential vessel diameters are $70 \mu \mathrm{m}$ (range 65-80 $\mu \mathrm{m}$ ) with 3-4 vessels per square $\mathrm{mm}$. Inter-vessel and vessel-parenchyma pits 

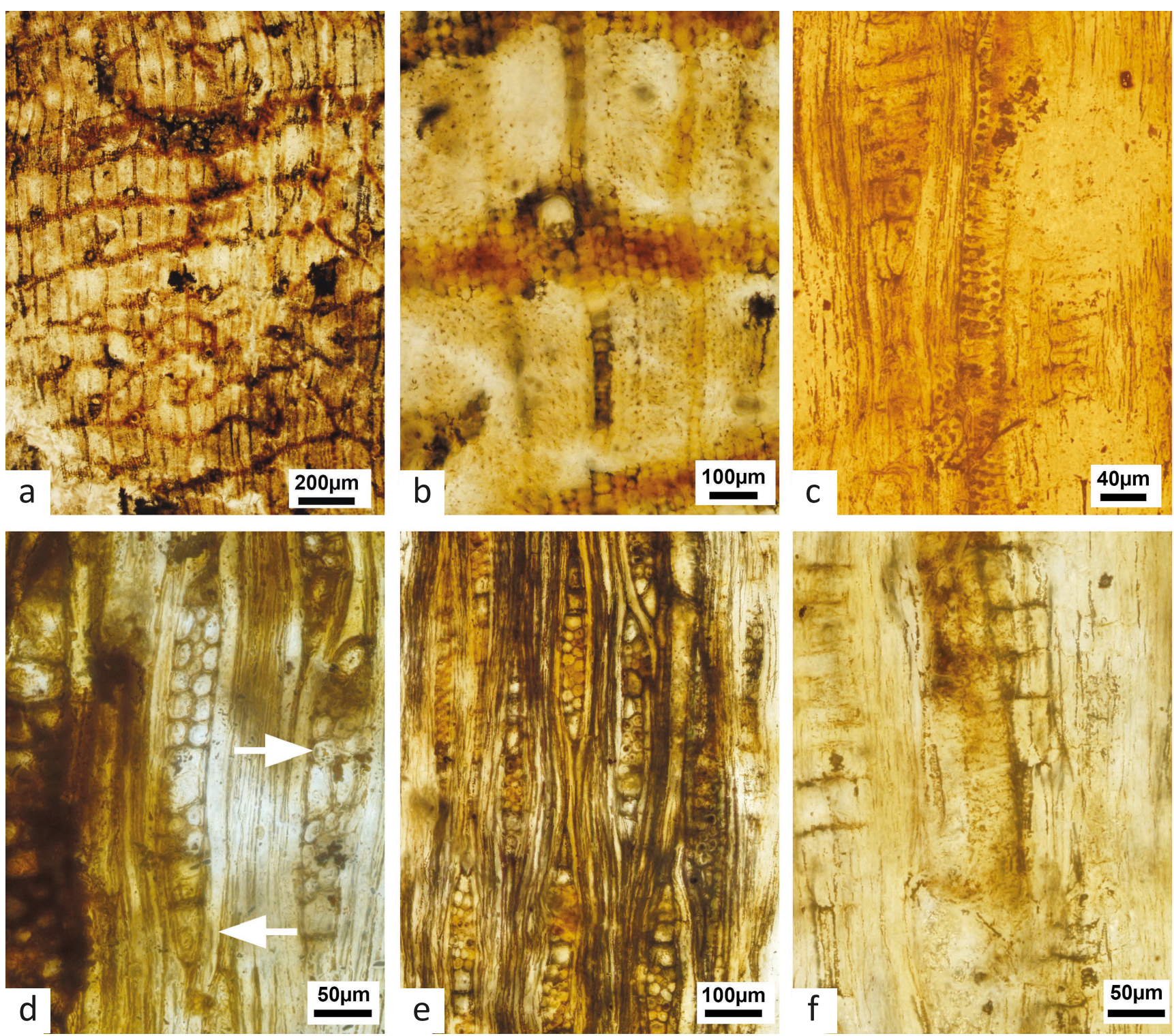

Text-fig. 15. Photomicrographs of thin sections of holotype BP/16/1738, Sorindeioxylon gorongosense gen. et sp. nov. from Muaredzi site 5, Gorongosa, Mozambique. a: TS, note the irregularly spaced and very narrow bands of parenchyma and mostly solitary vessel elements; b: TS at higher magnification with narrow rays; c: radial longitudinal section (RLS), rather oblique but shows the alternate, small-to-medium inter-vessel pits; $d$ : tangential longitudinal section (TLS), rays are 1-3 cells wide but maintain the same width. Small arrow towards the right hand ray indicates a prismatic crystal in the ray cell; e: TLS rays with fibres in between; f: RLS showing mixed ray cells (upright, square and procumbent) poorly preserved.

are alternate and 6-8 $\mu \mathrm{m}$, and well spaced in case of the vessel-ray pits (Text-fig. 15a, b). Perforation plates are simple and oblique. Parenchyma is not abundant, mostly vasicentric to rarely aliform, and there are narrow bands of $1-3$ cells wide with an irregular frequency (Text-fig. 15a, b). Prismatic crystals occur in the upright and square ray cells (Text-fig. 15d). Rays are 1-3 seriate and the width of the uniseriate part is the same as the multi-seriate part. They are heterocellular with mixed procumbent, square and upright cells. Rays are low with an average of 16 cells high (260 $\mu \mathrm{m}$ ) but up to twice that height.

Identification. One of the key features of this fossil wood is the presence of heterocellular rays with the uniseriate portions having the same width as the triseriate portions. This feature occurs in a few members of the Anacardiaceae, Apocynaceae, Euphorbiaceae, Rubiaceae and Sapotaceae and the combination of wood features narrows down to Sorindeia madagascariensis and Sorindeia spp. (InsideWood). The Gorongosa fossil wood features are a combination of these two entries. Since the modern database does not include all Sorindeia species and it is not certain that modern species were present (or recognisable) by the middle Tertiary, the fossil wood has been placed in a new fossil wood taxon, Sorindeioxylon.

Although the family is diverse in Africa today, the fossil wood record of the Anacardiaceae in the continent is very sparse. Only three examples from the Miocene to Pliocene of Ethiopia have been described and published (inventories of Dupéron-Laudoueneix and Dupéron 1995, Gregory et al. 2009; InsideWood database, accessed Oct 2021). Gregory et al. (2009) mentions four other fossil woods from Africa but they are either undescribed (Lannea sp., Lannea welwitschi; Dechamps 1976) and not mentioned in the 
InsideWood database, or are so poorly assigned (Unnamed, ?Anacardiaceae/Moraceae/Lauraceae; Kamal El-Din et al. 2006) that it is difficult to follow. The fourth example is the only one to be added to our list, Ozoroa insignis (Dechamps 1983, Dechamps and Maes 1985) but the rays are different from the Mozambican wood.

Anacardioxylon sorindeoides is similar to the Gorongosa wood except that the vessels are much larger and it has no banded parenchyma (Lemoigne 1978). From the same site in the Omo Valley, Glutoxylon symphonioides has even larger vessels and wider and taller rays, but it does have some banded parenchyma (Lemoigne 1978). The Gorongosa wood does not have the features of the other genera of fossil Anacardiaceae from other continents, so a new genus is proposed for this wood, Sorindeioxylon, and in recognition of the region, the type species is named gorongosense. Ozoroa insignis (Dechamps 1983, Dechamps and Maes 1985) from the Omo valley Pliocene deposits, has much wider rays than the Gorongosa wood together with 1-4 or more rows of marginal upright cells, so they are not comparable.

Anacardiaceae are cosmopolitan and occupy a wide variety of habitats. In southern Africa today there are ten genera of trees and shrubs: Abrahamia (formerly Protorhus), Harpephyllum, Lannea, Loxostylus, Ozoroa, Pseudospondias, Searsia (formerly Rhus), Sclerocarya, Sorindeia and Trichoscypha. The past diversity is unknown. The fossil wood anatomy shares some similarities with these genera but there are too many differences. Sorindeia madagascariensis occurs in northern Mozambique today in riverine forests or in open woodland, and is a small to medium height tree (Burroughs et al. 2018). It is the only member of this genus in Mozambique. The fossil wood Sorindeioxylon gorongosense gen. et sp. nov., therefore, indicates a local environment with sufficient sustained water for the growth of medium sized trees. Northern Mozambique, wedged between the huge rift floor lake, Lake Niassa (or Lake Malawi) and the east tropical coast, experiences summer rainfall and high temperatures.

\section{Family Combretaceae R.Br., 1810 nom. cons.}

\section{Genus Terminalioxylon E.SCHÖNFELD, 1947}

Ty p e. Terminalioxylon naranjo E.SCHÖNFELD.

Terminalioxylon mozambicense sp. nov. Text-fig. 16

H o l o ty p e. BP/16/1734 (Text-fig. 16).

Plant Fossil Names Registry Number. PFN002687 (for new species).

Additional material. BP/16/1731, 1735, 1736, 1737.

R e p o s i t o r y. Curated at the Palaeobotany Herbarium, Evolutionary Studies Institute (previously the Bernard Price Institute), University of the Witwatersrand, Johannesburg, South Africa (for both holotype and additional material).

Etymology. The species name is for Mozambique with the latin suffix ense meaning "from".
Ty p e 1 o c a lity. Mhengere Hill, Site $3\left(18^{\circ} 56^{\prime} 02.0^{\prime \prime} \mathrm{S}\right.$, $\left.34^{\circ} 36^{\prime} 50.6^{\prime \prime} \mathrm{E}\right)$. Fossil wood associated with palaeopan, lower northwest slope (Text-fig. 8), probably late Eocene.

Diagnosis. The wood is diffuse porous and growth rings are absent to indistinct. Vessels are arranged in short radial multiples, often solitary but with lines of two or three pores. Some vessels are tylosed, and range in diameter from 145-175 $\mu \mathrm{m}$ (Text-fig. 16a-c). Perforation plates are simple and horizontal. Inter-vessel pits are alternate and 6-8 $\mu \mathrm{m}$ and vessel-parenchyma pits are the same (Text-fig. 16a, b). Parenchyma is scanty paratracheal to vasicentric and also diffuse (Text-fig. 16a). There are 2-4 cells per parenchyma strand. Prismatic crystals occur in the diffuse parenchyma cells and the ray cells (Text-fig. 16d-g). Rays are exclusively uniseriate and up to 16 cells high $(175-400-500 \mu \mathrm{m})$, and procumbent body cells with 1-2 rows of marginal, square or upright cells that are difficult to see because of the dark cell contents (Text-fig. 16i). No canals were seen.

$\mathrm{Com}$ pari s o n s. The Gorongosa wood is very similar to Terminalioxylon tunesense DuPÉRON-LAUDOUEN. described from the late Oligocene to early Miocene of Tunisia (DelteilDesneux 1981) except that the vessels of the Gorongosa wood are smaller, it has rare diffuse parenchyma with prismatic crystals, as well as crystals in the ray cells (like the Tunisian specimen). Vessel size is not a reliable taxonomic feature and the presence of diffuse parenchyma is easy to miss. The geographic separation of the two sites is considerable so in order to avoid unreliable phytogeographic correlations, the Gorongosa wood has been placed in a new species.

There are 57 examples of fossil Terminalioxylon woods listed in the InsideWood database but none of them is compatible with the Gorongosa wood samples. For example, only ten of the listed woods have diffuse parenchyma. Of these ten, only three have rays with only one row of upright marginal cells (Terminalioxylon chiedense, T. coriaceum and T. felixii). Terminalioxylon chiedense has wider rays, 1-2 cells with the uniseriate portion as wide as the multiseriate portion (Fessler-Vrolant 1980). Terminalioxylon coriaceum has some vessels more than $200 \mu \mathrm{m}$ in diameter and confluent parenchyma (Licht et al. 2014). Terminalioxylon felixii has intervessel pits that are $10 \mu \mathrm{m}$ wide, some confluent parenchyma, terminal parenchyma bands and tyloses (Lakhanpal et al. 1984). None of these described woods matches the Gorongosa woods.

Four other species of Terminalioxylon and one fossil Terminalia L. have been described from Tertiary rocks of Africa (Terminalioxylon crystallinum M.K.BAMFORD and Terminalioxylon orangense M.K.BAMFORD from the middle Miocene of Namibia (Bamford 2003); Terminalioxylon welkitii Lemoigne et J.BeAuch. from the Miocene of Ethiopia (Lemoigne and Beauchamp 1972); Terminalia preglaucescens BANDE, Dechamps, R.N.LAKH. et U.PraKash from the early Miocene of Zaire (Bande et al. 1987)). The species vary slightly in average vessel diameters and degree of heterogeneity of the ray cells. None has diffuse parenchyma recorded.

Trees of the Combretaceae are common in southern Africa with members of Combretum and Terminalia being the most common. In Mozambique today there are about 11 species of Terminalia (out of a worldwide total 

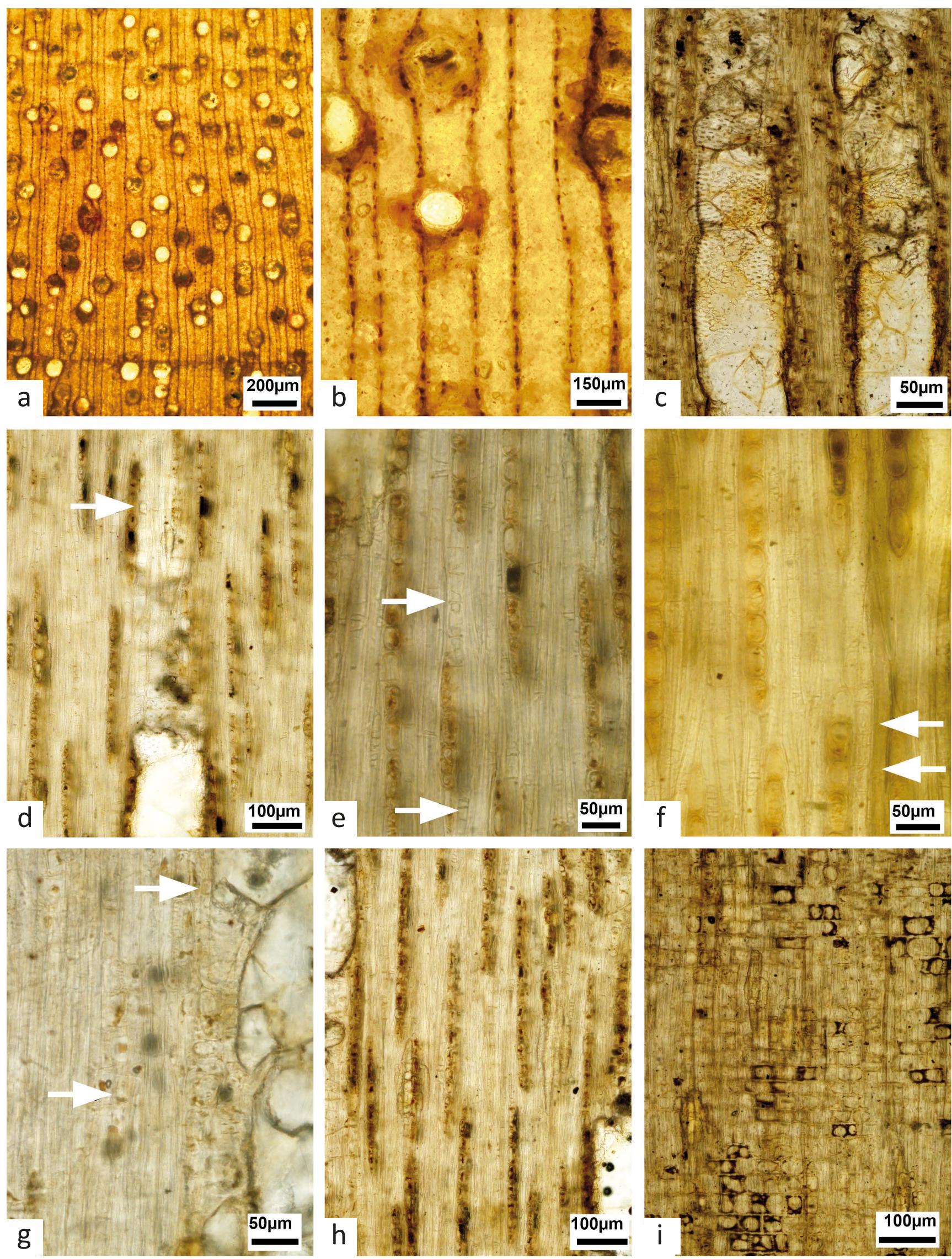

Text-fig. 16. Photomicrographs of thin sections of specimen BP/16/1734, Terminalioxylon mozambicense sp. nov. from Mhengere Hill, Gorongosa, Mozambique. a: TS with round vessels, scanty paratracheal to vasicentric parenchyma, diffuse and narrow terminal or initial bands; b: TS at higher magnification, note the very narrow rays; c: TLS, vessels with small alternate pits, and partly tylosed; d-g: TLS with crystals (small white arrows) in the parenchyma cells, medium to thick-walled fibres and uniseriate, low rays; h: TLS, rays up to 20 cells high; i: RLS rays with procumbent body cells and 1-2 rows of marginal upright cells. 


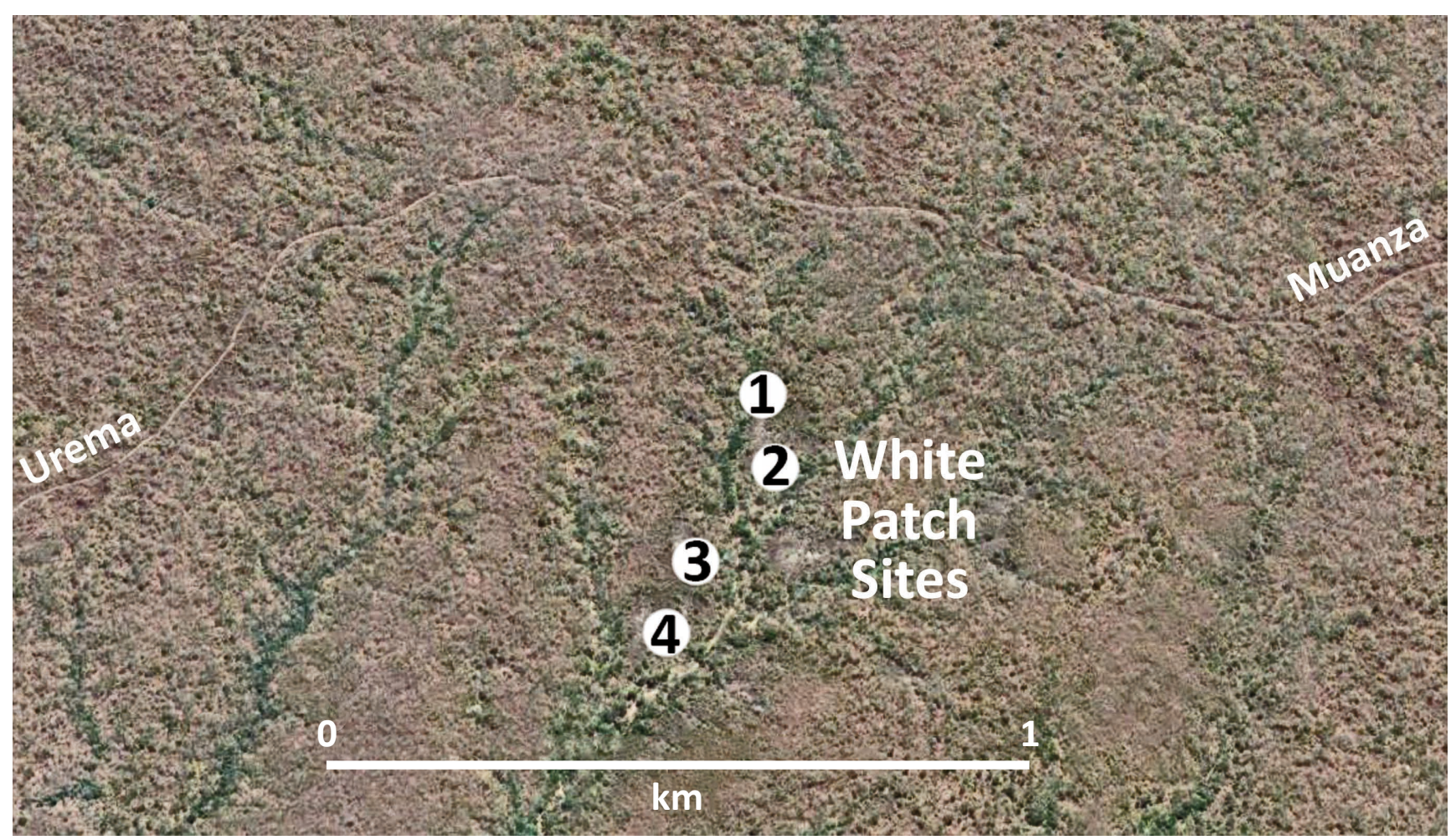

Text-fig. 17. White Patch fossil sites $\left(1^{\circ} 56^{\prime} 10.9^{\prime \prime} \mathrm{S}: \mathbf{3 4}^{\circ} 38^{\prime} 41.0^{\prime \prime} \mathrm{E}\right)$ Gorongosa National Park, south of the $4 \times 4$ vehicle track from Urema to Muanza. 1 - Marine molluscs, 2 - Bones, 3 - Bones, 4 - Marine snails (these sites were subsequently named GPL 12 and GPL 12b by d'Oliveira Coelho et al. 2021). Image modified from Google Earth.

of 150). Other genera include Lumnitzera, Meiostemon and Pteleopsis (Burroughs et al. 2018). Woods of the Combretaceae have been well studied (van Vliet 1978) and the genera are distinguishable. In Mozambique today there are ten species of Terminalia, all trees or shrubs, and their habitats range from rocky hillsides and ravines, Miombo woodland and forest to low altitude woodland (Burroughs et al. 2018). Extrapolating the environmental setting for the fossil wood from the modern analogues it is possible to infer that a tropical wooded environment was likely to be the setting.

\section{Systematic palaeontology}

\section{Phylum Mollusca Linnaeus, 1758}

Description. Fossil remains of marine molluscs were found at several localities between the Muaredzi and Muanza rivers (Text-fig. 17). Most of the material is preserved as steinkerns (Text-fig. 18) but one specimen preserves the shell and shows the characteristic sculpture of spiral ridges that occurs in species of Turritella (Textfig. 19). Fossil oyster shells are also present at the sites. These deposits occur up to 113 metres above present day sea-level.

R e marks. At several localities north of the UremaMuanza track, Habermann et al. (2019) recorded marine molluscs including Striostrea margaritacea, serpulid worm tubes, calianassid crustaceans, gastropods (Cerithiidae, Rhinoclavis, possibly Terebralia palustris) and barnacles. In addition, they inferred the presence of Muricidae on the basis of drill holes in some of the mollusc shells.

\section{Phylum Chordata HaEckel, 1874 \\ Subphylum Vertebrata LAMARCK, 1801 \\ Class Mammalia LinnAeus, 1758}

Description. During the 2013 survey fossilised mammal bones were found in the Mazamba Formation at two localities (White Patch Bone Site and White Patch 2) (Text-fig. 17). The fossils are reasonably well preserved, but no teeth were found. The bones were tentatively attributed to seals by Pickford (2013). However, further comparison with a range of large mammals shows a closer resemblance between the proximal ulna from White Patch Bone Site to those of the embrithopod Arsinoitherium BEADNELL, 1902, but from a considerably smaller species that Arsinoitherium zitteli. As the word embrithopod (heavy foot) signifies, the bone is heavily constructed (Andrews 1906).

The proximal right ulna from the White Patch Site (specimen WP 1; Text-fig. 20) has a low but solidly constructed olecranon process (Text-fig. 20b) with a shallow articulation for the humerus. The medial side of the olecranon is slightly concave, as in mammals in general. Sirenians in contrast, possess almost cylindical olecranon processes with a hemispherical apex, and for this reason, appurtenance of the White Patch ulna to this group of marine mammals can be discounted. The medial and lateral parts of the articular process have broken off (dotted lines in Text-fig. 20c) but the bone is otherwise in good condition. The diaphysis is broken off immediately beneath the humeral articulation, but it was evidently massive as shown by the solid cross section. The overall aspect of the specimen accords with Arsinoitherium, but it is considerably smaller than the ulna of Arsinoitherium zitteli (Beadnell 1902), belonging to an animal about the same size as the extant pygmy hippopotamus, Choeropsis liberiensis (Morton 1849). 

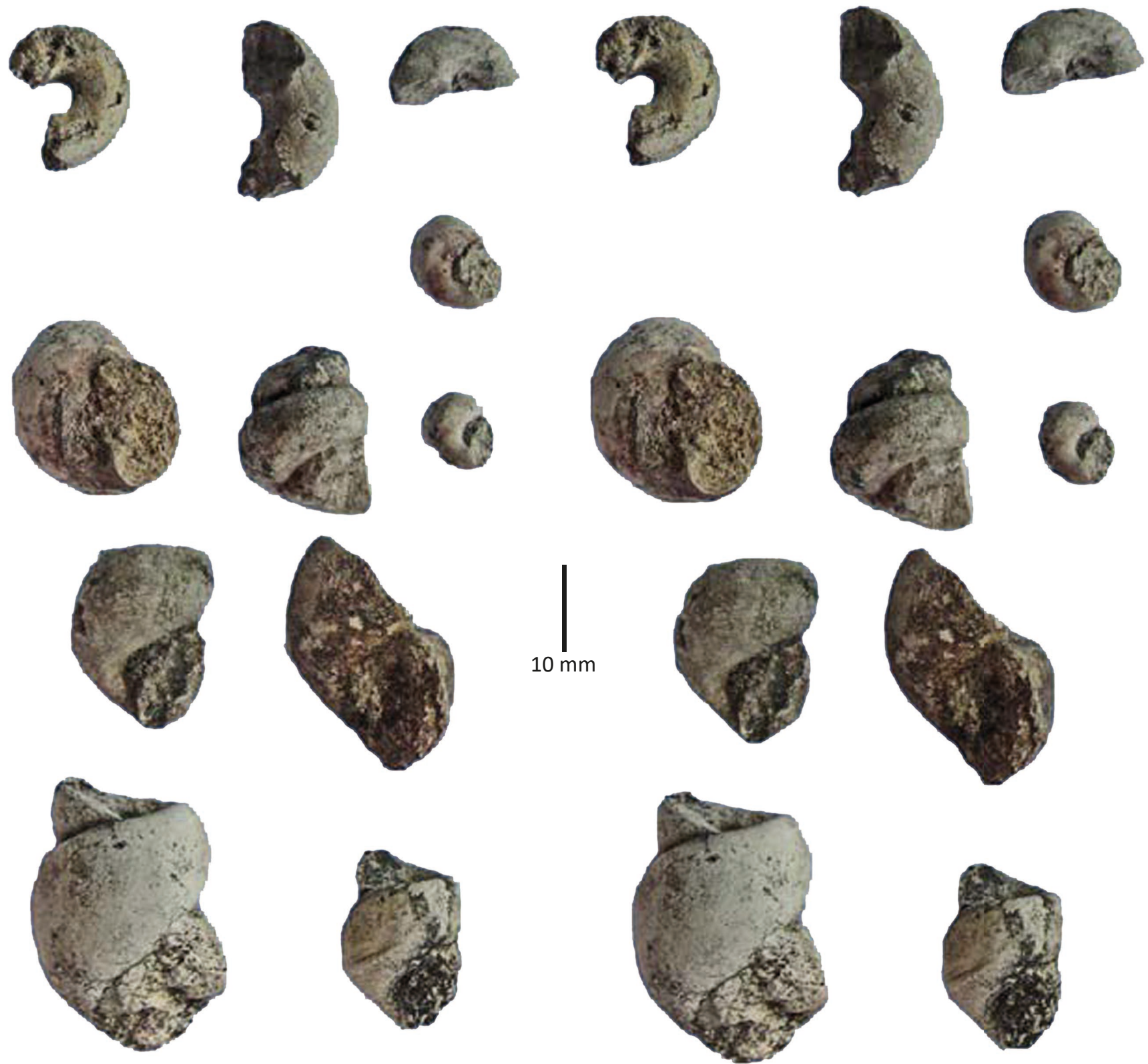

Text-fig. 18. Stereo images of fossil marine gastropod steinkerns from White Patch Fossil Site 1.
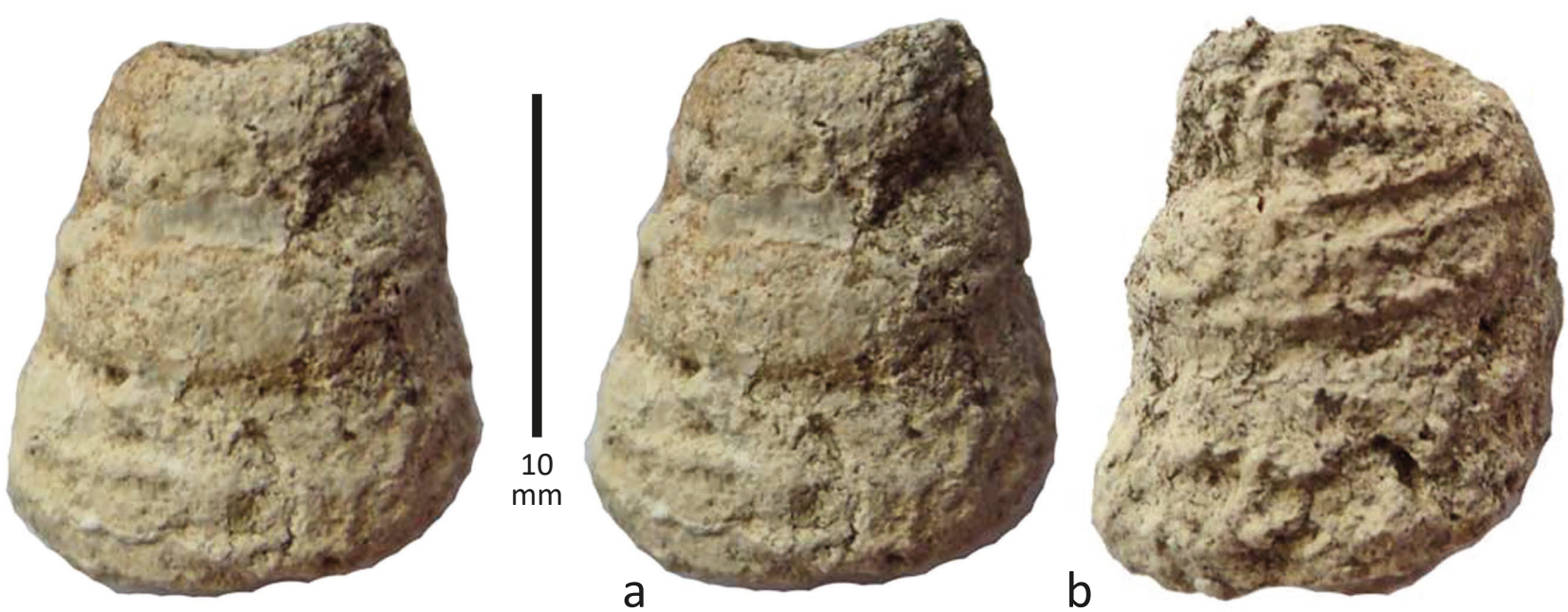

Text-fig. 19. Turritella shell from White Patch Fossil Site 1. a: stereo lateral view; b: obverse view to show the spiral ridges. 


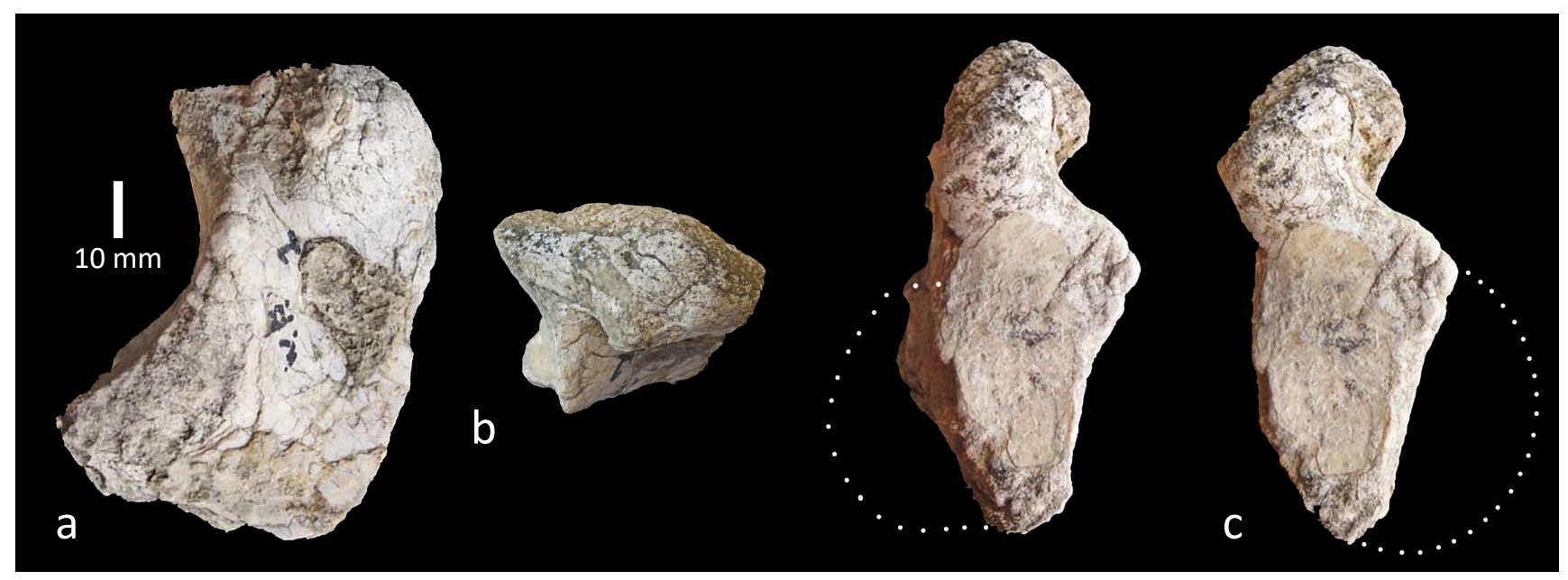

Text-fig. 20. Proximal right ulna of an embrithopod from White Patch Bone Site. a: lateral view; b: proximal view (anterior to the left); c: stereo view of the articular surface for the humerus. Note the damaged medial and lateral sides of the articular surface (dotted lines) which makes the distal part of the articular surface look narrower than it would have been in life.

The head of the femur from the White Patch Site is not fused to the diaphysis (Text-fig. 21). It is hemispherical, with a large and deep ligamentary fossa (fossa for the ligamentum teres femoralis) as in Arsinoitherium (Andrews 1906). The fossil is similar in dimensions to those of pygmy hippopotami.

The two mammal bones from the White Patch Site belong to species that was about the size of a pygmy hippopotamus (body weight between 180 and $275 \mathrm{~kg}$ (Eltringham 1993, 1999)). Because the ulna is heavily constructed, it suggests affinities with the Embrithopoda (heavy foot in Greek). The strength of the ligamentary fossa in the femur head also indicates that the species concerned was heavily built, but more informative material is required for a confident identification.

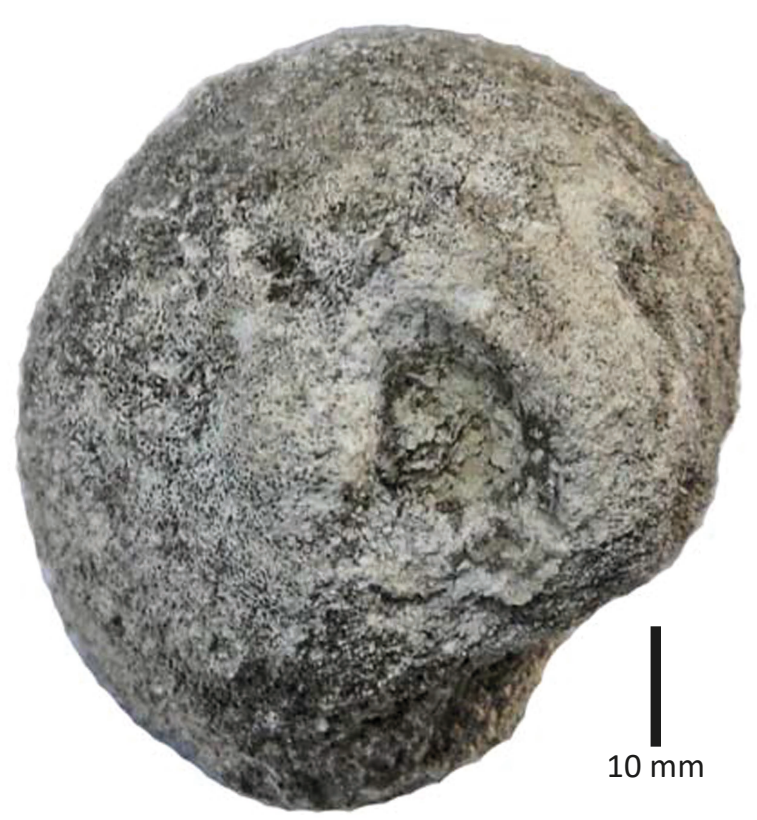

Text-fig. 21. Femur head from White Patch Bone Site belonging to a large mammal approximately the size of a pygmy hippopotamus, probably an embrithopod. View of ligamentary fossa.

\section{Summary and conclusions}

The Tertiary sediments exposed on the eastern shoulders of the Urema Rift Valley, the southern termination of the African Rift System, locally known as the Cheringoma Plateau, comprise a base of Cheringoma Limestone (marine deposits of middle Eocene age: Lutetian - late Bartonian) overlain by a variable thickness (ca. 130 metres) of Mazamba Formation (shallow marine, lagoonal, deltaic and fluviopalustral sediments associated with palaeopan deposits, probably of early Priabonian age) which are overlain by Inhaminga Formation sandstones (possibly Oligo-Miocene) and Plio-Pleistocene to Recent alluvial deposits and soils.

The interplay between rifting activity, sea-level changes (eustacy), erosion, sediment transport and deposition in the Urema sector of the African Rift is poorly understood. The deposits attributed to the Mazamba Formation were previously correlated broadly to the Mio-Pliocene on the basis that they overlie the Eocene Cheringoma Limestone, but renewed examination of the outcrops in the MuaredziMuanza sector of the plateau suggests the absence of an unconformable relationship between the Cheringoma and Mazamba formations, in which case there is unlikely to be a significant time gap between the two units (Lächelt 2004, Pfaffhuber et al. 2009). If so, then the Mazamba Formation in this area is more likely to correlate to the late Bartonian to early Priabonian. Fossil collections from the Mazamba unit (Pickford 2013, Habermann et al. 2019) will undoubtedly throw light on the matter. There could be early Miocene sediments in the same area but none have, as yet, been confidently identified.

From a palaeoenvironmental perspective, the most intriguing fossils found at Gorongosa consist of abundant well-preserved silicified wood and stems present at various levels in the Mazamba Formation. Three species of fossil plants have been identified from the eight samples collected from Mhengere Hill and Muaredzi Hill, Palmoxylon dutoitii, Sorindeioxylon gorongosense and Terminalioxylon mozambicense. The respective families, Arecaceae, Anacardiaceae and Combretaceae, are well represented in southern Africa today. As an assemblage the fossil woods 
and stems indicate a woodland vegetation in a warm, frostfree environment with a near-surface water table providing sufficient moisture to support medium sized trees. The presence of palaeopans also suggests a high water table.

Of interest from a biostratigraphic point of view, is the attribution of two fossil postcranial bones to the order Embrithopoda, a group of mammals that is unknown from Miocene and younger strata (Sanders et al. 2010). Within the context of arsinoitheres, the relatively small dimensions of the bones suggest that they belonged to a species comparable in size to the extant pygmy hippopotamus, and thus about the same size as the primitive arsinoithere, Namatherium blackcrowense (Pickford et al. 2008) from the Lutetian of Namibia, in which case they are likely to represent a taxon older than any of the Fayum and later taxa, all of which are considerably larger (Andrews 1906).

From the sedimentological perspective, the most interesting deposits are the sandy limestones that crop out as sub-circular hills (Mhengere, Muaredzi Palaeopan) which appear to represent palaeopans. The deposits in these hills show suncracks indicating exposure of sediments at the surface, and the upper levels have been silicified to chert facies. Further study of these deposits is clearly warranted in order to throw light on the sedimentary development of the region. Apart from these palaeopans, the Mazamba Formation comprises a variety of shallow marine, coastal, lagoonal and fluvio-palustral sediments (Habermann et al. 2019) which yield both marine and terrestrial fossils.

\section{Acknowledgements}

Thanks to the Gorongosa Park authorities (Mateus Mutemba, Vasco Galante, Marc Stalmans, James Glasgow) for arranging access to the Cheringoma Plateau. Particular thanks are due to Tongai Castigo (Gorongosa) who accompanied the second author in the field. Thanks to R. Govender (Iziko Museum, Cape Town) for information about marine mammal postcranial bones. Thanks also to PAST (Palaeontological Scientific Trust, South Africa) for funds for the Palaeobotany comparative collection over the past decade, and the NRF (National Research Foundation, South Africa) for equipment. Mrs Prosper Bande of the Evolutionary Studies Institute (ESI) is thanked for making the thin sections. Remarks by two referees led to improvement of the manuscript and figures.

\section{References}

Abrard, R. (1928): L'Éocène de Cheringoma (Moçambique). - Compte Rendu sommaire des séances de la Société géologique de France, Sér. 4, 28: 91-92.

Andrews, C. W. (1906): A Descriptive Catalogue of the Tertiary Vertebrata of the Fayûm, Egypt. - British Museum of Natural History, London, 324 pp.

Arbonnier, M. (2002): Trees, Shrubs and Lianas of West African Dry Zones. - Muséum National d'Histoire Naturelle, Paris; CIRAD, Versailles; Margraf, Weikersheim, 573 pp.

Baker, W. J., Dransfield, J. (2016): Beyond Genera Palmarum: progress and prospects in palm systematics. -
Botanical Journal of the Linnean Society, 182: 207-233. https://doi.org/10.1111/boj.12401

Bamford, M. K. (2003): Fossil woods from Auchas and their palaeoenvironment. - Memoir of the Geological Survey of Namibia, 19: 23-34.

Bande, M. B., Dechamps, R., Lakhanpal, R. N., Prakash, U. (1987): Some new fossil woods from the Cenozoic of Zaire. - Rapport Annuel du Département de Géologie et de Minéralogie du Musée Royal de l'Afrique Centrale, Tervuren, 1985-1986: 113-140.

Beadnell, H. J. C. (1902): A Preliminary Note on Arsinoitherium zitteli Beadnell, from the Upper Eocene Strata of Egypt. - Egyptian Survey Department, Public Works Ministry, Cairo, 4 pp. https://doi.org/10.5962/bhl.title.77308

Beentje, H. J. (1994): Kenya Trees, Shrubs and Lianas. National Museums of Kenya, Nairobi, 722 pp.

Berggren, W. G. (1998): The Cenozoic Era: Lyellian (chrono)stratigraphy and nomenclatural reform at the millenium. - Special Publications, Geological Society, London, 143: 111-132. https://doi.org/10.1144/GSL.SP.1998.143.01.10

Beyrich, H. E. (1854): Über die Stellung der Hessischen Tertiärbildungen. - Bericht über die zur Bekanntmachung geeigneten Verhandlungen der Königlich Preußischen Akademie der Wissenschaften zu Berlin, 1854: 640-666.

Burkill, H. M. (1997): The useful plants of West Tropical Africa (2nd Edition). Volume 4, Families M-R. - Royal Botanic Gardens, Kew, Richmond, 969 pp.

Burroughs, J. E., Burroughs, S. M., Lötter, M. C., Schmidt, E. (2018): Trees and Shrubs Mozambique. - Publishing Print Matters (Pty) Ltd, Noordhoek, Cape Town, 1124 pp.

Dartevelle, E. (1935): Les premiers restes de Mammifères du Tertiaire du Congo: La faune Miocène de Malembe. Comptes Rendus du 2ème Congrès national des sciences, Brussels, 1: 715-720.

Dechamps, R. (1976): Résultats préliminaires de l'étude des bois fossiles de la basse vallée de l'Omo (Ethiopie sud occidentale). - Rapport Annuel du Département de Géologie et de Minéralogie du Musée Royal de l'Afrique Centrale, Tervuren, 1975: 59-65.

Dechamps, R. (1983): Fossil woods (in article by R. Bonnefille and R. Dechamps). - In: Heinzelin, J. de (ed.), The Omo group: archives of the International Omo Research Expedition. Annales du Musée Royal d'Afrique Centrale, Tervuren, sér. en- $8^{\circ}$, Sciences Géologique, 85 : 191-198.

Dechamps, R., Maes, F. (1985): Essai de reconstitution des climats et des végétations de la basse vallée de l'Omo au Plio-Pleistocène à l'aide de bois fossiles. In: Coppens, Y. (ed.), Environnement des Hominoïdés au Plio-Pléistocène, Colloque International, June 1981. Fondation Singer-Polignac, Masson, Paris, pp. 175-222.

Delteil-Desneux, F. (1981): Sur l'association de trois bois fossiles dans un même gisement tertiaire du Djebel Nara (Tunisie centrale). - Review of Palaeobotany and Palynology, 31: 289-310. https://doi.org/10.1016/0034-6667(80)90032-9

Dransfield, J. (1986): Palmae. - In: Polhill, R. M. (ed.), Flora of Tropical East Africa. Published on behalf of the East African Governments by Balkema, Rotterdam, $56 \mathrm{pp}$. 
Dransfield, J., Uhl, C. B., Asmussen, C. B., Baker, W. J., Harley, M. M., Lewis, C. E. (2005): A new phylogenetic classification of the palm family, Arecaceae. - Kew Bulletin, 60: 559-569.

Dupéron-Laudoueneix, M., Dupéron, J. (1995): Inventory of Mesozoic and Cenozoic woods from Equatorial and North Equatorial Africa. - Review of Palaeobotany and Palynology, 84: 439-480.

https://doi.org/10.1016/0034-6667(94)00047-N

Eltringham, S. K. (1993): The pygmy hippopotamus (Hexaprotodon liberiensis). - In: Oliver, W. L. R. (ed.), Pigs, Peccaries, and Hippos. IUCN, Gland, pp. 55-60.

Eltringham, S. K. (1999): The Hippos. - Academic Press, London, $184 \mathrm{pp}$.

Endlicher, S. L. (1837): Genera plantarum. Fasc. 4. - Fr. Beck, Wien, pp. 241-320.

Ferrara, M., Manninen, T. (2006): Map Sheet 1834, Gorongosa, 1/250,000. - Direcçaõ Nacional de Geologia, Ministério dos Recursos Minerais, Republica de Moçambique.

Ferrara, M., Manninen, T., Lehto, T., Korkiaskoski, E. (2006): Map Sheet 1834, Gorongosa, 1/250,000, Levantamento geológico efectuado por / Mapped by. - In: Ferrara, M., Manninen, T., Map Sheet 1834, Gorongosa, 1/250,000. Direcçaõ Nacional de Geologia, Ministério dos Recursos Minerais, Republica de Moçambique.

Fessler-Vrolant, C. (1980): Étude de quelques bois de Tunisie. - In: Comptes Rendus du 105ème Congrès National de la Société des Savants, Caen, 1980, Sciences, vol. 1, pp. 197-224.

Flores, G. M. (1964): Geology of the Cheringoma uplift; unpublished report. - MS, Relatorios inéditos da Mozambique Gulf Oil, Maputo, Mozambique. (copy in library of Mozambique Gulf Oil, Maputo)

Flores, G. M. (1973): The Cretaceous and Tertiary sedimentary basins of Mozambique and Zululand. - In: Blant, G. T. (ed.), Sedimentary Basins of the African Coasts. Part II, South and East Coast. Association of African Geological Surveys, Paris, pp. 81-111.

Förster, R., Martin, M., Wachendorf, H. (1982): Afrika Kartenwerk - Geologie Südafrika. Beiheft zu Blatt 3. Gebrueder Borntraeger, Berlin, 111 pp.

Gradstein, F. M., Ogg, J. G., Schmitz, M. D., Ogg, G. M. (2020): Geologic Time Scale 2020. Volume 2. - Elsevier, Amsterdam, Oxford, Cambridge, pp. 563-1357.

Grantham, G. H., Marques, J. M., Wilson, M. G. C., Manhiça, V., Hartzer, F. J. (2011): Explanation of the Geological Map of Mozambique, Scale 1 : 1000 000. - Direcção Nacional de Geologia, Republica de Moçambique, Ministerio dos Recursos Minerais e Energia, Maputo, 383 pp.

Gregory, M., Poole, I., Wheeler, E. A. (2009): Fossil dicot wood names, an annotated list with full bibliography. IAWA Journal, Supplement 6: 1-220.

GTK Consortium (2006): Notícia Explicativa [Explanatory notes]. Volume 1: Geologia das Folhas [Geology of map sheets] 2032/2033, 2034/2035, 2131/2132, 2133, 2134/2135, 2231, 2232, 2233, 2234/2235, 2331/2332, $2333,2334 / 2335,2431 / 2432,2433,2434 / 2435$, 2531/2532, 2533/2534 e 2632. Volume 2: Geologia das Folhas [Geology of map sheets] 1631, 1632, 1633, 1634,
1732, 1733, 1734, 1832, 1833, 1834, 1932, 1933 e 1934. Volume 3: Geologia das Folhas [Geology of map sheets] 1735-1736-1737/1738/1739-1835-1836-1935. Volume 4: Geologia das Folhas [Geology of map sheets] 1430432 e 1530-534, Escala [scale] 1:250.000. - Direcção Nacional de Geologia, Ministério dos Recursos Minerais, Maputo, Moçambique. (in Portuguese)

Habermann, J. M., Alberti, M., Aldeias, V., Alemseged, Z., Archer, W., Bamford, M., Biro, D., Braun, D. R., Capelli, C., Cunha, E., Ferreira da Silva, M., Lüdecke, T., Madiquida, H., Martinez, F. I., Mathe, J., Negash, E., Paulo, L. M., Pinto, M., Stalmans, M., Regala, F. T., Wynn, J. G., Bobe, R., Carvalho, S. (2019): Gorongosa by the sea: First Miocene fossil sites from the Urema Rift, Central Mozambique, and their coastal paleoenvironmental and paleoecological contexts. Palaeogeography, Palaeoclimatology, Palaeoecology, 514: 723-738.

https://doi.org/10.1016/j.palaeo.2018.09.032

Harley, M. (2006): A summary of fossil records for Arecaceae. - Botanical Journal of the Linnean Society, 151: 39-67. https://doi.org/10.1111/j.1095-8339.2006.00522.x

Hooijer, D. A. (1963): Miocene mammals of Congo. Annales du Musée Royal de l'Afrique Centrale, Série 8: Sciences géologiques, 46: 1-77.

IAWA Committee (1989): IAWA list of microscopic features for hardwood identification. - IAWA Bulletin, new series, 10: 219-332.

InsideWood (2004-onwards): Published on the Internet. http://insidewood.lib.ncsu.edu/search [accessed 20202021].

Kaiser, E. (ed.) (1926): Die Diamantenwüste SüdwestAfrikas, Bd. 2. - Dietrich Reimer, Berlin, 535 pp.

Kamal El-Din, M. M., Wheeler, E. A., Bartlett, J. A. (2006): Cretaceous woods from the Farafra Oasis, Egypt. IAWA Journal, 27: 137-143. https://doi.org/10.1163/22941932-90000143

Kaul, K. N. (1945): A fossil palm stem from South Africa (Palmoxylon dutoitii), sp. nov. - Proceedings of the Linnean Society of London, 156(3): 197-198. https://doi.org/10.1111/j.1095-8312.1945.tb00393.x

Klopper, R. R., Chatelain, C., Bänninger, V., Habashi, C., Steyn, H. M., de Wet, B. C., Arnold, T. H., Gautier, L., Smith, G. F., Spichiger, R. (2006): Checklist of flowering plants of sub-Saharan Africa. An index of accepted names and synonyms (South African Botanical Diversity Network Report No. 42). - Southern African Botanical Diversity Network (SABONET), Pretoria, 894 pp.

Lächelt, S. (2004): Geology and Mineral Resources of Mozambique. - Direcção Nacional de Geologia Moçambique, Maputo, 515 pp.

Lakhanpal, R. N., Guleria, J. S., Awasthi, N. (1984): The fossil floras of Kachchh. III. Tertiary megafossils. - The Palaeobotanist, 33: 228-319.

Laumanns, M. (2001): Mozambique 1998. Report on the European speleological project "Cheringoma 1998". Berliner Höhlenkundliche Berichte, 2: 85 pp. +7 annexes.

Lemoigne, Y. (1978): Flores tertiaires de la Haute Vallée de l'Omo (Ethiopie). - Palaeontographica, Abt. B, 165: 80-157. 
Lemoigne, Y., Beauchamp, J. (1972): Paléoflores tertiaires de la région de Welkite (Ethiopie, province du Shoa). Bulletin de la Société géologique de France, 7ème série, 14: 336-352. https://doi.org/10.2113/gssgfbull.S7-XIV.1-5.336

Licht, A., Boura, A., De Franceschi, D., Ducrocq, S., Aung Naing Soe, Jaeger, J. J. (2014): Fossil woods from the late middle Eocene Pondaung Formation, Myanmar. Review of Palaeobotany and Palynology, 202: 29-46. https://doi.org/10.1016/j.revpalbo.2013.12.002

Mennell, F. P. (1929): Some Mesozoic and Tertiary Igneous Rocks from Portuguese East Africa. - The Geological Magazine, 66(12): 529-540.

https://doi.org/10.1017/S0016756800102419

Morton, S. G. (1849): Additional observations on a new living species of hippopotamus. - Journal of the Academy of Natural Sciences, Philadelphia, 2: 231-239.

Newton, R. B. (1915): Fossils from Portuguese East Africa referred to in discussion on Teale and Wilson's paper on the Geology of that country. - Geographical Journal, 45: 43.

Newton, R. B. (1924): Appendix B. A contribution to the Palaeontology of Portuguese East Africa. - In: Teale, E. O., The Geology of Portuguese East Africa between the Zambesi and Sabi Rivers. Transactions of the Geological Society of South Africa, 26: 141-159, pl. 10.

Nour-El-Deen, S., Thomas, R., El-Saadawi, W. (2018): First record of fossil Trachycarpeae in Africa: three new species of Palmoxylon from the Oligocene (Rupelian) Gebel Qatrani Formation, Fayum, Egypt. - Journal of Systematic Palaeontology, 16(9): 741-766. https://doi.org/10.1080/14772019.2017.1343258

d'Oliveira Coelho, J., Anemone, R., Carvalho, S. (2021): Unsupervised learning of satellite images enhances discovery of late Miocene fossil sites in the Urema Rift, Gorongosa, Mozambique. - PeerJ, 9: e11573 (24 pp.). https://doi.org/10.7717/peerj.11573

Pan, A. D., Jacobs, B. F., Dransfield, J., Baker, W. J. (2006): The fossil history of palms (Arecaceae) in Africa and new records from the Late Oligocene (28-27 Mya) of north-western Ethiopia. - Botanical Journal of the Linnean Society, 151: 69-81. https://doi.org/10.1111/j.1095-8339.2006.00523.x

Pfaffhuber, A. A., Monstad, S., Rudd, J. (2009): Airborne electromagnetic hydrocarbon mapping in Mozambique. - Exploration Geophysics, 40: 1-9. https://doi.org/10.1071/EG09011

Pickford, M. (1986): Première découverte d'une faune mammalienne terrestre paléogène d'Afrique subsaharienne. - Comptes Rendus de l'Académie des Sciences, Paris, 302: 1205-1210.

Pickford, M. (1987): Recognition of an early Oligocene or late Eocene mammal fauna from Cabinda, Angola. Rapport Annuel du Département de Géologie et de Minéralogie du Musée Royal de l'Afrique Centrale, Tervuren, 1985-1986: 89-92.

Pickford, M. (1998): Onland Tertiary marine strata in southwestern Africa: eustasy, local tectonics and epeirogenesis in a passive continental margin setting. South African Journal of Science, 94: 5-8.

Pickford, M. (2012): Moçambique Palaeontology Reconnaisance, November, 2012; Unpublished Report. -
MS, Muséum National d'Histoire Naturelle, Paris, $22 \mathrm{pp}$. (copy in personal library of M. Pickford and at Gorongosa Park Headquarters)

Pickford, M. (2013): Moçambique Palaeontology Reconnaisance, November, 2013; Unpublished Field Report. MS, Muséum National d'Histoire Naturelle, Paris, 13 pp. (copy in personal library of M. Pickford and at Gorongosa Park Headquarters)

Pickford, M. (2015): Cenozoic Geology of the Northern Sperrgebiet, Namibia, accenting the Palaeogene. Communications of the Geological Survey of Namibia, 16: 10-104.

Pickford, M., Senut, B., Morales, J., Mein, P., Sanchez, I. M. (2008): Mammalia from the Lutetian of Namibia. - Memoir of the Geological Survey of Namibia, 20: 465-514.

Ponte, J.-P., Robin, C., Guillocheau, F., Popescu, S., Suc, J.-P., Dall'Asta, M., Melinte-Dobrinescu, M. C., Bubik, M., Dupont, G., Gaillot, J. (2019): The Zambezi Delta (Mozambique Channel, East Africa): High resolution dating combining bio-orbital and seismic stratigraphies to determine climate (palaeoprecipitation) and tectonic controls on a passive margin. - Marine and Petroleum Geology, 105: 293-312. https://doi.org/10.1016/j.marpetgeo.2018.07.017

Real, F. (1966): Geologia da Bacia do Rio Zambeze (Moçambique) [Geology of the Zambezi River Basin (Mozambique)]. - Junta de Investigaçaõ do Ultramar, Lisboa, Imprensa Portuguesa, Porto, 183 pp., 57 plates, 2 geological maps, 1 p. errata (in Portuguese)

Said, A., Moder, C., Clark, S., Ghorbal, B. (2015): Cretaceous-Cenozoic sedimentary budgets of the Southern Mozambique Basin: Implications for uplift history of the South African Plateau. - Journal of African Earth Sciences, 100: 1-10.

https://doi.org/10.1016/j.jafrearsci.2015.05.007

Salard-Cheboldaeff, M., Dejax, J. (1991): Evidence of Cretaceous to Recent West African intertropical vegetation from continental sediment spore-pollen analysis. - Journal of African Earth Sciences, 12: 353-361. https://doi.org/10.1016/0899-5362(91)90084-C

Sanders, W. J., Rasmussen, D. T., Kappelman, J. (2010): Embrithopoda. - In: Werdelin, L., Sanders, W. J. (eds), Cenozoic Mammals of Africa. University of California Press, Berkeley, Los Angeles, London, pp. 115-122. https://doi.org/10.1525/california/9780520257214. 003.0012

Seiffert, E. (2010): Chronology of Paleogene Mammal Localities. - In: Werdelin, L., Sanders, W. J. (eds), Cenozoic Mammals of Africa. University of California Press, Berkeley, Los Angeles, London, pp. 19-26. https://doi.org/10.1525/california/9780520257214. 003.0002

Serra-Kiel, J. Hottinger, L., Caus, E., Drobne, K., Ferrandez, C., Jauhri, A. K., Less, G., Pavolvec, R., Pignatti, J., Samso, J. M., Schaub, H., Sirel, E., Strougo, A., Tambareau, Y., Tosquella, J., Zakrevskaya, E. (1998): Larger foraminiferal biostratigraphy of the Tethyan Paleocene and Eocene. - Bulletin de la Société géologique de France, 169(2): 281-299.

Scoon, R. (2016): Africa's Top Geological Sites - Produced for the $35^{\text {th }}$ International Geological Congress in Cape 
Town. - Struik Nature, a division of Penguin Random House (Pty) Ltd., Cape Town, pp. 44-47.

Steinbruch, F. (2010): Geology and geomorphology of the Urema Graben with emphasis on the evolution of Lake Urema. - Journal of African Earth Sciences, 58: 272-284. https://doi.org/10.1016/j.jafrearsci.2010.03.007

Teale, E. O. (1924): The geology of Portuguese East Africa between the Zambezi and Sabi Rivers. - Transactions of the Geological Society of South Africa, 26: 103-129.

Thiele, E. O., Wilson, R. C. (1915): Portuguese East Africa between the Zambezi River and the Sabi River: a Consideration of the Relation of its Tectonic and Physiographic Features. - Geographical Journal, 45: 16-45. https://doi.org/10.2307/1779983

Thomas, R., De Franceschi, D. (2013): Palm stem anatomy and computer-aided identification: The Coryphoideae (Arecaceae). - American Journal of Botany, 100: 289-313. https://doi.org/10.3732/ajb.1200242

Tinley, K. L. (1977): Framework of the Gorongosa Ecosystem; DSc Thesis. - MS, University of Pretoria, South Africa, 184 pp. +10 pp. unnumbered annexes. (copy in library of M. Pickford, also in the University of Pretoria Library and at Gorongosa Park Headquarters) du Toit, A. L. (1929): The Geology of South Africa. $2^{\text {nd }}$ ed. Oliver and Boyd, Edinburgh, London, $447 \mathrm{pp}$.

Tomlinson, P. B. (2006): The uniqueness of palms. Botanical Journal of the Linnean Society, 151: 5-14. https://doi.org/10.1111/j.1095-8339.2006.00520.x

Türtscher, J., Lopez-Romero, F. A., Jambura, P. L., Kindlimann, R., Ward, D. J., Kriwet, J. (2021, on-line): Evolution, diversity, and disparity of the tiger shark lineage Galeocerdo in deep time. - Paleobiology, 17 pp. https://doi.org/10.1017/pab.2021.6

Uhl, N., Dransfield, J. (1987): Genera Palmarum: A Classification of Palms Based on the Work of Harold E. Moore Jr. - Allen Press, Lawrence, Kansas, 610 pp.

Vaudois-Miéja, N., Lejal-Nicol, A. (1987): Paléocarpologie africaine: apparition dès l'Aptien en Égypte d'un palmier (Hyphaeneocarpon aegyptiacum n. sp.). - Comptes Rendus de l'Académie des Sciences, Paris, Ser. II, 304(6): 233-238.

van Vliet, G. J. C. M. (1978): Wood anatomy of the Combretaceae. - Blumea, 115: 171-223.

van Wyk, B., van Wyk, P. (2013): Field Guide to Trees of Southern Africa. $2^{\text {nd }}$ ed. - Struik Publishers, Cape Town, 732 pp. 